\title{
Geochemical Landscapes of the Conterminous United States- New Map Presentations for 22 Elements
}

U.S. Geological Survey Professional Paper 1648

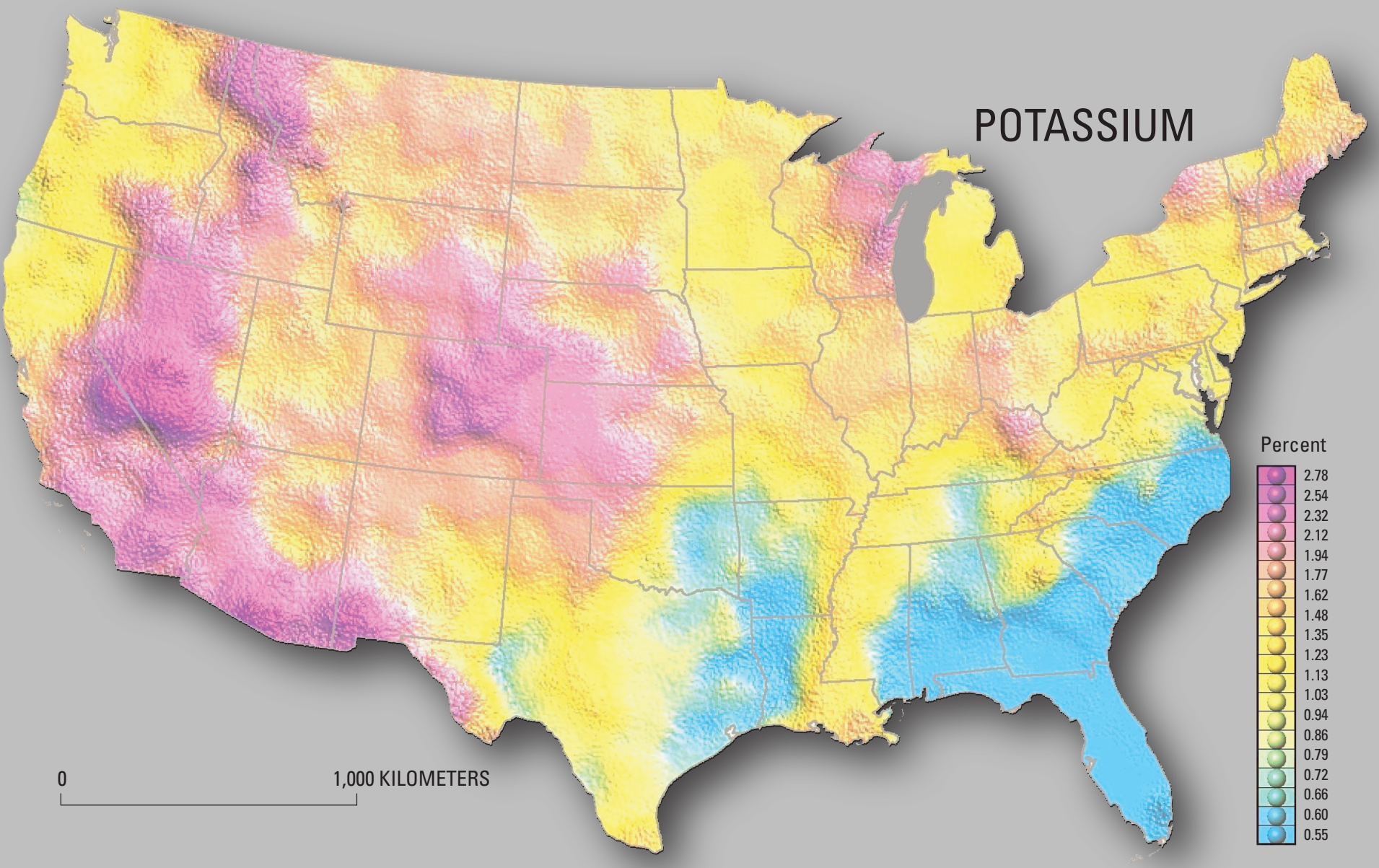




\section{Geochemical Landscapes of the Conterminous United States- New Map Presentations for 22 Elements}

By N. Gustavsson, B. Bølviken, D.B. Smith, and R.C. Severson

U.S. Geological Survey Professional Paper 1648 


\title{
U.S. Department of the Interior
}

\author{
Gale A. Norton, Secretary
}

\section{U.S. Geological Survey}

Charles G. Groat, Director

First printing November 2001

For sale by U.S. Geological Survey, Information Services Box 25286, Denver Federal Center

Denver, CO 80225

This publication is also available online at: http://pubs.usgs.gov/pp/p1648/

Any use of trade, product, or firm names in this publication is for descriptive purposes only and does not

imply endorsement by the U.S. Government 


\section{Contents}

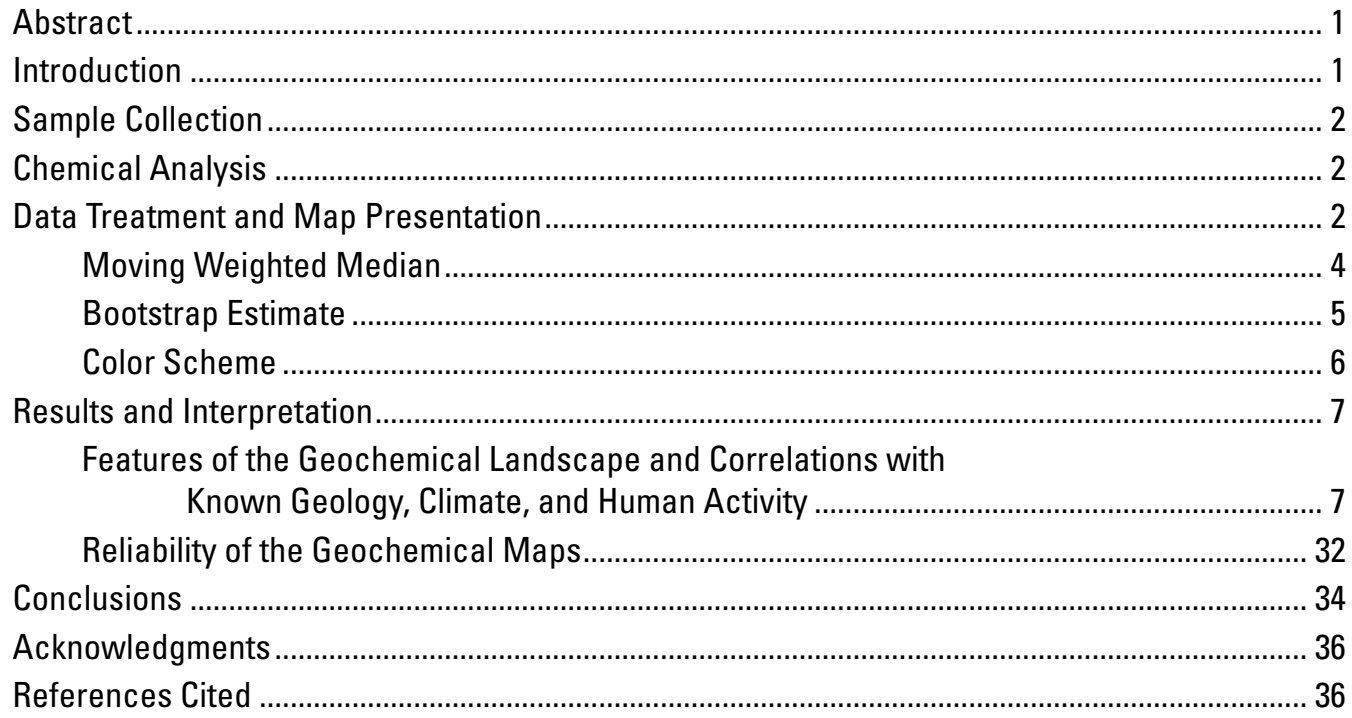

\section{Figures}

1. Map showing geochemical sample stations ……....................................................... 3

2. Curve representing the local weight function (Butterworth's) depending on the distance of the sampling station to the center of a circular window...................... 6

3. Colored surface map of Al distribution in soils and other surficial materials of the conterminous United States .................................................................................. 8

4. Colored surface map of As distribution in soils and other surficial materials of the conterminous United States .................................................................................. 9

5. Colored surface map of Ba distribution in soils and other surficial materials of the conterminous United States 10

6. Colored surface map of $\mathrm{Ca}$ distribution in soils and other surficial materials of the conterminous United States

7. Colored surface map of $\mathrm{Cr}$ distribution in soils and other surficial materials of the conterminous United States

8. Colored surface map of Cu distribution in soils and other surficial materials of the conterminous United States

9. Colored surface map of Fe distribution in soils and other surficial materials of the conterminous United States

10. Colored surface map of $\mathrm{Hg}$ distribution in soils and other surficial materials of the conterminous United States

11. Colored surface map of $\mathrm{K}$ distribution in soils and other surficial materials of the conterminous United States 
12. Colored surface map of Li distribution in soils and other surficial materials of the conterminous United States.....

13. Colored surface map of Mg distribution in soils and other surficial materials of the conterminous United States.

14. Colored surface map of Mn distribution in soils and other surficial materials of the conterminous United States

15. Colored surface map of $\mathrm{Na}$ distribution in soils and other surficial materials of the conterminous United States.

16. Colored surface map of Ni distribution in soils and other surficial materials of the conterminous United States

17. Colored surface map of $\mathrm{Pb}$ distribution in soils and other surficial materials of the conterminous United States

18. Colored surface map of Se distribution in soils and other surficial materials of the conterminous United States.

19. Colored surface map of Sr distribution in soils and other surficial materials of the conterminous United States.

20. Colored surface map of Ti distribution in soils and other surficial materials of the conterminous United States

21. Colored surface map of $\mathrm{V}$ distribution in soils and other surficial materials of the conterminous United States.

22. Colored surface map of $Y$ distribution in soils and other surficial materials of the conterminous United States

23. Colored surface map of $\mathrm{Zn}$ distribution in soils and other surficial materials of the conterminous United States

24. Colored surface map of Zr distribution in soils and other surficial materials of the conterminous United States.

25. Map of conterminous United States showing approximate location of selected physiographic and geologic features

26. Plot of $\mathrm{K}$ in regolith from sample-collection phase 1 versus sample-collection phase 2

27. Potassium map of conterminous United States derived from aerial gamma-ray surveys.

28. Plot of $\mathrm{K}$ in regolith versus radiometric $\mathrm{K}$ at the corresponding nearest point

29. Map of conterminous United States showing the moving correlation (Spearman-rank correlation coefficient) between $\mathrm{K}$ in regolith samples and $\mathrm{K}$ determined by airborne gamma-ray surveys

\section{Tables}

1. Methods of chemical analysis for selected elements in soil samples

2. Summary information on chemical analysis of the 22 elements plotted as geochemical maps in figures 3-24 
3. Parameter settings for computing regular grid using Bootstrap estimates of the moving weighted median......

4. Quartiles and relative quartile deviations of interpolated and smoothed data for each element. 


\title{
Geochemical Landscapes of the Conterminous United States- New Map Presentations for 22 Elements
}

\author{
By N. Gustavsson, ${ }^{1}$ B. Bølviken, ${ }^{2}$ D.B. Smith, ${ }^{3}$ and R.C. Severson ${ }^{3}$
}

\section{Abstract}

Shacklette and Boerngen (1984) collected soil and other regolith samples from 1,323 sites in the conterminous United States $\left(7,840,000 \mathrm{~km}^{2}\right)$ and prepared single-element pointsymbol geochemical maps in black and white for 7 major and 39 trace elements. We have reprocessed these data, using weighted-median and Bootstrap procedures for interpolation and smoothing, and produced full-color maps for seven major elements ( $\mathrm{Al}, \mathrm{Ca}, \mathrm{Fe}, \mathrm{K}, \mathrm{Mg}, \mathrm{Na}$, and $\mathrm{Ti}$ ) and 15 trace elements (As, Ba, Cr, Cu, Hg, Li, Mn, Ni, Pb, Se, Sr, V, $\mathrm{Y}, \mathrm{Zn}$, and $\mathrm{Zr}$ ). Comparison of the $\mathrm{K}$ map produced in this manner with a corresponding map obtained from airborne radiometric measurements of ${ }^{40} \mathrm{~K}$ indicates that the reliability of the soil maps is good even with this ultra low sample density.

Many broad geochemical dispersion patterns for both major and trace elements have been delineated. Some of these agree with known geologic and physiographic features, whereas others seem to reflect variations in natural parameters such as soil type and climate. Certain patterns may be due to pollution, and others are difficult to interpret in view of the present knowledge.

It is concluded that geochemical maps based on ultra low density sample distributions, such as those presented in this publication, should have potential use in various fields. This type of map may be used to (1) establish general baselines against which more specific natural geochemical variations and human-induced perturbations can be appraised, (2) reflect large underlying geologic features and therefore delineate geochemical provinces of interest in exploration for mineral resources, (3) show how geochemical patterns in the regolith are influenced by natural features such as soil type, climate, and vegetation, (4) provide a basis for research within the field of geomedicine (environmental

\footnotetext{
${ }^{1}$ Geological Survey of Finland.

${ }^{2}$ Geological Survey of Norway.

${ }^{3}$ U.S. Geological Survey.
}

geochemistry and health), and (5) show large geochemical contrasts between continents.

\section{Introduction}

In their paper "Element concentrations in soils and other surficial materials of the conterminous United States," Shacklette and Boerngen (1984) published a number of geochemical point-symbol maps (Howarth, 1983) covering the conterminous United States. The maps were based on chemical analyses of 1,323 samples of soils or other regolith materials collected, primarily, along the network of existing roads. At that time, such a low sampling density was not considered adequate to generate reproducible results. Furthermore, the maps produced by Shacklette and Boerngen were not very illustrative. These are probably the two main reasons why the maps did not receive proper attention during the 1980's. Recent geochemical mapping has, however, shown that significant broad geochemical distribution patterns with distinct contrasts between subareas exist in many places, even at continental scale (Duval, 1990; Xie and Ren, 1993), and that these patterns may be recognized based on one sample per 1/1000 of the area studied (e.g., Bølviken and others, 1992; Eden and Björklund, 1994). It was in this context that the importance of the Shacklette and Boerngen data set was recognized during the early stages of the International Geological Correlation Program's Project 259/360 (International Geochemical Mapping) (Darnley and others, 1995). The data set was, at that time, and still is at the time of this publication, the only national geochemical data set for the conterminous United States that was generated according to consistent and standardized sampling and analytical protocols. As such, it presents an opportunity to obtain a first approximation of the geochemical landscape for this large area of the Earth's surface. We have, therefore, drawn new maps of Shacklette and Boerngen's data using modern computerized techniques and find the disclosed geochemical patterns so interesting that a republication of the maps is justified. 


\section{Sample Collection}

This summary of sampling and chemical analysis is based on the papers by Shacklette and others (1971), Boerngen and Shacklette (1981), and Shacklette and Boerngen (1984).

The sampling was done by U.S. Geological Survey (USGS) personnel at sampling stations located along their routes of travel to project areas and within project areas in various parts of the United States. The location of the stations, therefore, depended on both the road network and the destination of the samplers. The sample stations were selected approximately every $80 \mathrm{~km}$ along the roads, which resulted in a total of 1,323 stations, corresponding to an average of one sample station per $6,000 \mathrm{~km}^{2}$ for the conterminous United States. (It should be noted that there is some discrepancy in the number of samples in the above references. Although Shacklette and Boerngen (1984) state 1,318 samples were collected, seven of the geochemical maps $(\mathrm{Ba}, \mathrm{B}, \mathrm{Cr}, \mathrm{Pb}, \mathrm{V}, \mathrm{Y}$, and $\mathrm{Zr}$ ) in that publication show 1,319 samples were plotted. In addition, Boerngen and Shacklette (1981), in their tabulation of all the data generated in the study, show 1,323 samples. The current study used this data set of 1,323 samples as the basis for all the new maps shown in figures 3-24.) In most cases the stations were located at least $100 \mathrm{~m}$ from the road and at sites that had natural surficial materials supporting native plant growth. Occasionally, the distance to the road had to be reduced for practical reasons, and, in some areas, only cultivated fields were available for sampling.

The samples were collected in two phases during 1961-71 and 1971-75 resulting in 962 and 356 samples, respectively (fig. 1). (Based on the above-referenced publications, we found it impossible to fully reconcile the samples between the two phases of sample collection. Therefore, figure 1 distinguishes those samples we could unambiguously identify as phase- 1 and phase- 2 samples from those whose placement was uncertain.) One sample was collected at each selected station. The materials sampled included that part of the regolith that normally is defined as "soil" by soil scientists. About $0.25 \mathrm{~L}$ of soil was taken at a depth of $20 \mathrm{~cm}$ below the surface, which is normally in the B horizon of podzols or just below the plow zone in cultivated soils. The samples were packed in metal-free paper envelopes and shipped to the USGS laboratories in Denver, Colo., where they were oven-dried, pulverized if necessary, and sieved to a minus-2-mm fraction. This fraction was further milled to minus 200 mesh $(<75 \mu \mathrm{m})$ before analysis.

\section{Chemical Analysis}

Boerngen and Shacklette (1981) report analytical values for 46 elements analyzed by a variety of methods. Table 1 shows the analytical methods used to analyze the 22 elements discussed in this study. For some elements, the methods of chemical analysis were consistent throughout the duration of the project, whereas, for others, the methods were different in phase 1 and phase 2 (table 1). The use of different methods in phases 1 and 2 may complicate the interpretation of the data generated because the accuracy and precision may vary between phases. This type of problem will be discussed in more detail in the section on reliability of the maps.

Each of the analytical methods described in Boerngen and Shacklette (1981) and Shacklette and Boerngen (1984) gives the total contents of the element determined. Therefore, reported values from the different methods can be directly compared for each element. Similar analytical methods were used for a reconnaissance geochemical survey of the State of Missouri conducted by the USGS during 1969-73 (Conner and others, 1972; Tidball, 1974, 1976; Miesch, 1976). After testing the sampling and analytical reproducibility in this survey, Miesch (1976) concluded that the sampling errors were more significant than the analytical errors and that the application of more precise analytical methods would have been a waste of money. The Missouri geochemical survey included 7,000 samples taken within $180,000 \mathrm{~km}^{2}$ as opposed to 1,300 samples from $8,000,000 \mathrm{~km}^{2}$ in the survey reported here. This much lower sampling density, with a corresponding greater sampling error, indicates that the reproducibility of the analytical results reported by Shacklette and Boerngen (1984) is adequate even between sample-collection phases.

The data were censored by both lower and upper limits of determination (Shacklette and Boerngen, 1984). Fortunately, even though the analytical techniques changed for a few elements during the project (table 1), the determination limits remained constant. Table 2 summarizes the determination limits, the number of samples with censored values, the number of samples not analyzed for a given element, and the number of analyses plotted to generate the geochemical maps (figs. 3-24).

\section{Data Treatment and Map Presentation}

The Geological Survey of Finland produced the maps from data obtained from the USGS National Geochemical Database. The software employed has also been used for generating maps in national and international geochemical atlases (Koljonen and others, 1992; Lahermo and others, 1990; Gustavsson and others, 1994, 1995; Lahermo and others, 1996).

Among available presentation techniques, we chose color surface maps (Gustavsson and others, 1997) to show regionalscale trends in element content. Color surface maps are generated from gridded data. Each grid node corresponds to a pixel, which is assigned a color depending on the local interpolated and smoothed concentration level. A basic problem in producing color surface maps is that the measurements tend to be irregularly located in the mapped area, whereas the pixels 


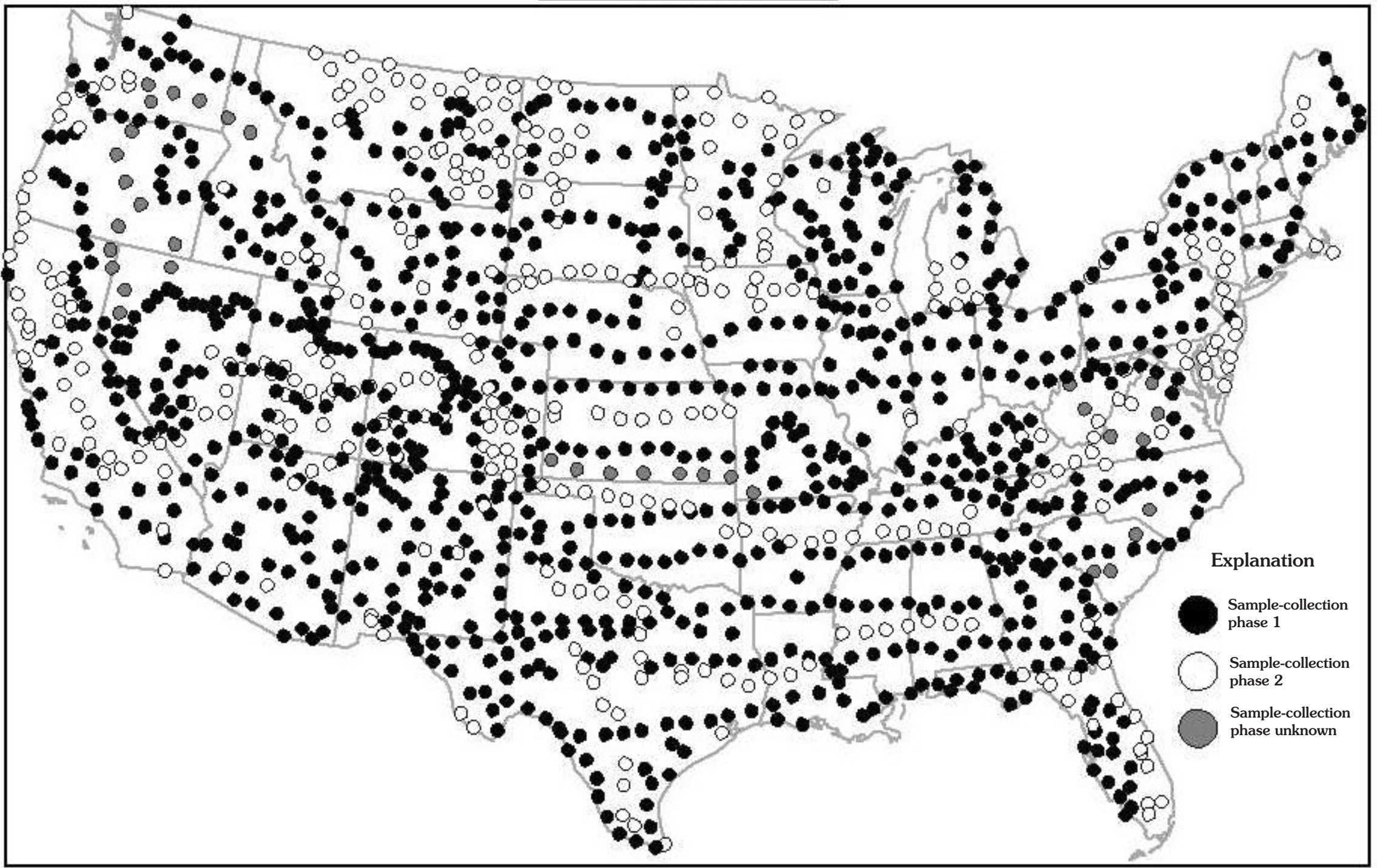

Figure 1. Map showing geochemical sample stations. Black dots indicate samples from sample-collection phase 1, white dots indicate samples from sample-collection phase 2, gray dots indicate samples whose placement into phase 1 or phase 2 is uncertain. 
Table 1. Methods of chemical analysis for selected elements in soil samples.

[References are in footnotes]

\begin{tabular}{|c|c|c|c|}
\hline \multirow{2}{*}{\multicolumn{2}{|c|}{ Element }} & \multirow{2}{*}{\multicolumn{2}{|c|}{ Method of analysis }} \\
\hline & & & \\
\hline 1 & $\mathrm{Al}$ & Emission spectrography ${ }^{1}$ & Emission spectrography \\
\hline 2 & As & $\begin{array}{l}\text { Arsine evolution-spectrophotometric-isotope } \\
\text { dilution }{ }^{2}\end{array}$ & $\begin{array}{l}\text { Arsine evolution-spectrophotometric-isotope } \\
\text { dilution }\end{array}$ \\
\hline 3 & $\mathrm{Ba}$ & Emission spectrography & Emission spectrography \\
\hline 4 & $\mathrm{Ca}$ & EDTA titration & X-ray fluorescence spectrometry ${ }^{3}$ \\
\hline 5 & $\mathrm{Cr}$ & Emission spectrography & Emission spectrography \\
\hline 6 & $\mathrm{Cu}$ & Emission spectrography & Emission spectrography \\
\hline 7 & $\mathrm{Fe}$ & Emission spectrography & X-ray fluorescence spectrometry \\
\hline 8 & $\mathrm{Hg}$ & Flame and flameless atomic absorption ${ }^{4}$ & Flame and flameless atomic absorption ${ }^{4}$ \\
\hline 9 & $\mathrm{~K}$ & Flame photometry 5 & X-ray fluorescence spectrometry \\
\hline 10 & $\mathrm{Li}$ & Emission spectrography & Flame atomic absorption \\
\hline 11 & $\mathrm{Mg}$ & Emission spectrography & Flame atomic absorption \\
\hline 12 & $\mathrm{Mn}$ & Emission spectrography & Emission spectrography \\
\hline 13 & $\mathrm{Na}$ & Emission spectrography & Flame atomic absorption \\
\hline 14 & $\mathrm{Ni}$ & Emission spectrography & Emission spectrography \\
\hline 15 & $\mathrm{~Pb}$ & Emission spectrography & Emission spectrography \\
\hline 16 & $\mathrm{Se}$ & X-ray fluorescence spectrometry & X-ray fluorescence spectrometry \\
\hline 17 & $\mathrm{Sr}$ & Emission spectrography & Emission spectrography \\
\hline 18 & $\mathrm{Ti}$ & Emission spectrography & X-ray fluorescence spectrometry \\
\hline 19 & V & Emission spectrography & Emission spectrography \\
\hline 20 & Y & Emission spectrography & Emission spectrography \\
\hline 21 & $\mathrm{Zn}$ & Colorimetry 5 & Flame atomic absorption \\
\hline 22 & $\mathrm{Zr}$ & Emission spectrography & Emission spectrography \\
\hline
\end{tabular}

${ }^{1}$ Myers and others (1961); Neiman (1976).

${ }^{2}$ Huffman and Dinnin (1979).

${ }^{3}$ Wahlberg (1976).

${ }^{4}$ Huffman and Dinnin (1976).

${ }^{5}$ Ward and others (1963).

form a regular grid. For decades, interpolation and smoothing techniques have been employed to compute "best" and least misleading surfaces from values on an irregular grid. Many of these techniques work well for evenly distributed data points, but difficulties may arise when the data set is sparse. Stable results for sparse data sets typically require more smoothing, which leads to fewer details. We chose Bootstrap estimates (Efron and Tibshirani, 1991; Stuart and Ord, 1987) of the moving weighted median (Björklund and Lummaa, 1983) to achieve robustness against local outliers.

\section{Moving Weighted Median}

Calculation of the moving weighted median to interpolate a continuous "surface" from scattered point data involves computing, for each grid cell, the median of distance-weighted observation values found within a circle of radius $\mathrm{R}$ from the center of the cell. Assume a circular window centered at a pixel and containing $n$ observed sampling points with measured values $x_{i}$. The values are sorted in ascending order. For odd $n$, the ordinary unweighted moving median is then $x_{(n+1) / 2}$, and, for even $n$, a value between $x_{n / 2}$ and $x_{n / 2+1}$ is computed by linear interpolation (Stuart and Ord, 1987). The unweighted moving median does not depend on the spatial position of the sampling points. Every sampling point carrying a value is at a distance $d_{i}$ from the window center. Given a weight function $W$, the corresponding weight of value $x_{i}$ at distance $d_{i}$ is $w_{i}=W\left(d_{i}\right)$. Now, the frequencies $f_{i}$ (equal to $1 / n$ ) of $x_{i}$ are adjusted by the weights yielding new weighted frequencies $g_{i}$ by 
Table 2. Summary information on chemical analysis of the 22 elements plotted as geochemical maps in figures 3-24.

\begin{tabular}{|c|c|c|c|c|c|c|c|}
\hline Element & $\begin{array}{c}\text { Concentration } \\
\text { units }\end{array}$ & $\begin{array}{l}\text { Detection } \\
\text { limit }\end{array}$ & $\begin{array}{c}\text { Upper } \\
\text { determination } \\
\text { limit }\end{array}$ & $\begin{array}{c}\text { Number of } \\
\text { samples } \\
\text { missing analysis }\end{array}$ & $\begin{array}{c}\text { Number of } \\
\text { samples with } \\
\text { analysis } \\
\text { below detection } \\
\text { limit }\end{array}$ & $\begin{array}{l}\text { Number of samples } \\
\text { with analysis above } \\
\text { upper determination } \\
\text { limit }\end{array}$ & $\begin{array}{c}\text { Number of } \\
\text { samples } \\
\text { plotted }\end{array}$ \\
\hline $\mathrm{Al}$ & $\%$ & 0.07 & 10 & 76 & 0 & 136 & 1,247 \\
\hline As & ppm & 0.01 & & 66 & 8 & & 1,257 \\
\hline $\mathrm{Ba}$ & ppm & 10 & & 4 & 0 & & 1,319 \\
\hline $\mathrm{Cr}$ & ppm & 1.0 & & 4 & 0 & & 1,319 \\
\hline $\mathrm{Cu}$ & ppm & 1.0 & & 12 & 10 & & 1,311 \\
\hline $\mathrm{Fe}$ & $\%$ & 0.01 & 10 & 6 & 0 & 2 & 1,317 \\
\hline $\mathrm{Hg}$ & ppm & 0.01 & & 56 & 4 & & 1,267 \\
\hline $\mathrm{K}$ & $\%$ & 0.01 & & 9 & 0 & & 1,314 \\
\hline $\mathrm{Li}$ & ppm & 5.0 & & 65 & 48 & & 1,258 \\
\hline $\mathrm{Pb}$ & ppm & 10 & & 4 & 185 & & 1,319 \\
\hline $\mathrm{Se}$ & $\mathrm{ppm}$ & 0.1 & & 56 & 228 & & 1,267 \\
\hline $\mathrm{Sr}$ & ppm & 5.0 & & 5 & 39 & & 1,318 \\
\hline $\mathrm{Ti}$ & $\%$ & 0.007 & & 6 & 0 & & 1,317 \\
\hline $\mathrm{V}$ & ppm & 7.0 & & 4 & 25 & & 1,319 \\
\hline $\mathrm{Y}$ & ppm & 10 & & 4 & 83 & & 1,319 \\
\hline $\mathrm{Zn}$ & ppm & 5.0 & & 75 & 9 & & 1,248 \\
\hline $\mathrm{Zr}$ & ppm & 20 & & 4 & 3 & & 1,319 \\
\hline
\end{tabular}

$$
g_{i}=f_{i} w_{i} / \sum_{i=1}^{n} w_{i}
$$

where,

the distance weights are rescaled to sum up to unity. The corresponding cumulative frequencies, $G\left(x_{k}\right)$, are expressed by

$$
G\left(x_{k}\right)=\sum_{i=1}^{k} g_{i} \quad, k=1, \ldots, n
$$

The moving weighted median is finally obtained by linear interpolation between $x_{k}$ and $x_{k+1}$ where $x_{k}$ is the greatest observed value with $G\left(x_{k}\right) \leq 0.5$. A bell-shaped function known as the Butterworth's function was here used for the distancedependent weights

$$
w=\frac{1}{1+\left(d / d_{0}\right)^{2 m}}
$$

where,

$d(0 \leq d \leq R)$ is the distance to the window center,

$d_{0}(>0)$ is a value indicating the distance at which the weight is halved, and

$m$ is the order effecting the steepness of the curve (Gonzales and Winz, 1987).
Finally $w$ is adjusted by a term depending on $R$ to achieve 0 at the window periphery. A large $d_{0}$ smears out details, whereas a small $d_{0}$ preserves them. A minimum number of samples in the window was also used.

The particular Butterworth function used for the maps is shown in figure 2 and the corresponding parameter values are given in table 3 . The parameter values are chosen by experience according to the scale of the map and the sampling density. The pixel size was chosen as $5 \times 5 \mathrm{~km}$ to yield a sufficiently smooth surface.

\section{Bootstrap Estimate}

A procedure termed "Bootstrap" (Efron and Tibshirani, 1991; Stuart and Ord, 1987) was used to estimate the average of repeated moving weighed medians within the window. A statistical sample of $n$ items was repeatedly drawn from the values within the window one value at a time with replacement (i.e., the same geochemical value may appear several times in the statistical sample). For the statistical sample drawn, the weighted median based on $n$ values was computed. This was repeated a number of times $(k)$, and the arithmetic mean of the $k$ weighted medians was computed. When drawing the 


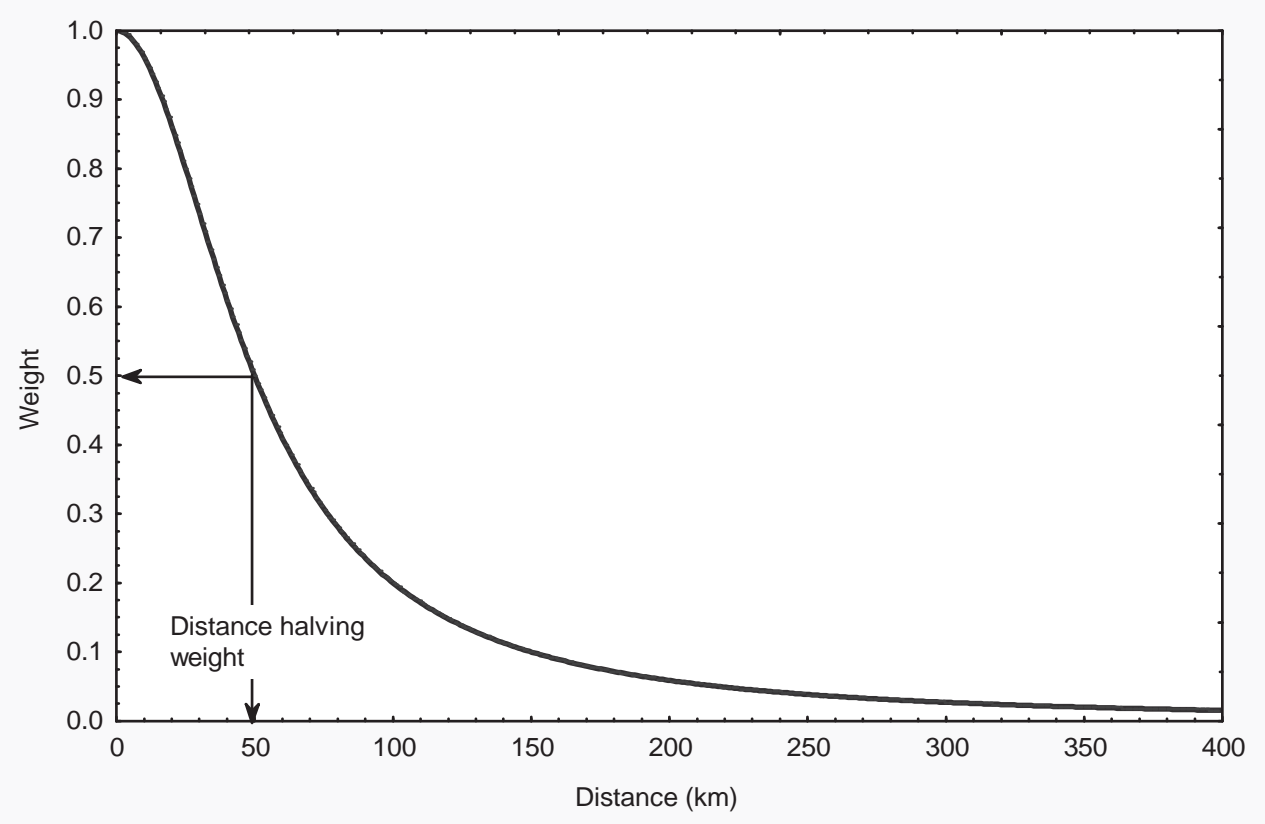

Figure 2. Curve representing the local weight function (Butterworth's) depending on the distance of the sampling station to the center of a circular window.

$k$ statistical samples at random, every geochemical sampling point has the same probability to be included. Because of the replacement, the most common values (several geochemical sampling points may have the same value) occur very often, whereas outliers are rarely included. Bootstrap estimates in overlapping interpolation windows yield less uncertainty than ordinary methods without repeated sampling. Furthermore, the sampling variance (variance between the statistical samples) can be estimated and shown on a map.

The sampling variance of the estimate can also be emphasized by "illuminating" the color surface to create the effect of shaded relief. Then the variation between neighboring pixels is shown as a grainy texture. The more uneven the surface, the more local variation is present in the data. The illuminated map shows not only the concentration level but also the local variation, which may reveal important regional geochemical features in the data (Gustavsson, 1995).

\section{Color Scheme}

The interpolated grid values (pixel values) are presented on a scale with 20 colors ranging from cyan (lowest 10 percent of values) to magenta (highest 1 percent of values). The color scale is tied at two percentiles of the empirical cumulative frequency curve of gridded values. The color-class intervals were derived by slicing the interval between these percentiles into equal-length slices on a logarithmic scale. When the analytical detection limit exceeded the lower percentile, the percentile was replaced by the detection limit.

The surface was illuminated by directed and ambient light in a lighting model presented by Strauss (1990). The resulting shaded-relief maps highlight subtle features, which may not be revealed on ordinary color maps. Shaded-relief maps are commonly produced by image-processing systems and by custom-written programs for geochemistry (Björklund and Gustavsson, 1987; Davenport and others, 1991).

To comprehensively show all possible effects due to relief shading of colors in the legend, each class is portrayed on an illuminated horizontal rectangle with a bubble (or hemisphere). All possible slopes on the map are represented on the surface of the bubble, and the reflection pattern shows where the directed light comes from.

The ambient light and a directed light source were located in the northeast and 30 degrees from the zenith. The maps were plotted in Albers Equal Area projection with standard parallels at lat $29^{\circ} 30^{\prime} \mathrm{N}$. and $45^{\circ} 30^{\prime} \mathrm{N}$. and the origin at lat $23^{\circ} \mathrm{N}$. and long $96^{\circ} \mathrm{W}$. (Snyder, 1987). The software for interpolation and plotting was written at the Geological Survey of Finland except for basic graphical and statistical procedures, which were invoked from the UNIRAS FGL/GRAPHICS ${ }^{\mathrm{TM}}$ library and the IMSL STAT/LIBRARYTM ${ }^{\mathrm{T}}$, respectively. 
Table 3. Parameter settings for computing regular grid using Bootstrap estimates of the moving weighted median.

\begin{tabular}{|c|c|c|c|}
\hline Subject & Parameter & Used value & Remarks \\
\hline \multirow[t]{2}{*}{ Grid } & Pixel size $(\mathrm{km} \times \mathrm{km})$ & $5 \times 5$ & \\
\hline & Number of pixels & $580 \times 920$ & total pixels 533,600 \\
\hline \multirow[t]{4}{*}{ Weighted median } & $\mathrm{R}$, window radius $(\mathrm{km})$ & 400 & $\begin{array}{l}\text { Average number of points in } \\
\text { window is } 63\end{array}$ \\
\hline & $\begin{array}{l}\mathrm{N}_{\min } \text {, the minimum number of points in } \\
\text { the window }\end{array}$ & 3 & \\
\hline & $d_{0}$, halving distance of weights $(\mathrm{km})$ & 50 & $\begin{array}{l}\text { Average number of points in } \\
\text { window within } d_{0} \text { is } 2\end{array}$ \\
\hline & $\begin{array}{l}m \text {, order of weight function affecting } \\
\text { steepness }\end{array}$ & 1 & \\
\hline \multirow[t]{2}{*}{ Bootstrap } & Sample size at resampling & average 63 & $\begin{array}{l}\text { Same as the number of values in } \\
\text { window }\end{array}$ \\
\hline & Number of repeated samples in window & 30 & Constant \\
\hline
\end{tabular}

Table 4. Quartiles and relative quartile deviations of interpolated and smoothed data for each element.

\begin{tabular}{|c|c|c|c|c|c|}
\hline & Element (unit) & $\begin{array}{l}\text { First quartile } 0_{1} \\
\quad(25 \%)\end{array}$ & $\begin{array}{c}\text { Second quartile } \mathrm{O}_{2} \\
(50 \%)\end{array}$ & $\begin{array}{c}\text { Third quartile } \mathrm{O}_{3} \\
\text { (75\%) }\end{array}$ & $\begin{array}{c}\text { Relative quartile } \\
\text { deviation } \\
\left(0_{3}-0_{1}\right) /\left(20_{2}\right)\end{array}$ \\
\hline 1 & $\mathrm{Al}(\%)$ & 3.47 & 5.14 & 6.83 & 0.33 \\
\hline 2 & As (ppm) & 4.21 & 5.57 & 7.06 & 0.26 \\
\hline 3 & $\mathrm{Ba}(\mathrm{ppm})$ & 307 & 502 & 680 & 0.37 \\
\hline 4 & $\mathrm{Ca}(\%)$ & 0.392 & 0.992 & 1.93 & 0.78 \\
\hline 5 & $\mathrm{Cr}(\mathrm{ppm})$ & 28.6 & 40 & 53.2 & 0.31 \\
\hline 6 & $\mathrm{Cu}(\mathrm{ppm})$ & 11.8 & 18.2 & 23.4 & 0.32 \\
\hline 7 & $\mathrm{Fe}(\%)$ & 1.48 & 1.95 & 2.59 & 0.28 \\
\hline 8 & $\mathrm{Hg}(\mathrm{ppm})$ & 0.0385 & 0.0518 & 0.0739 & 0.34 \\
\hline 9 & $\mathrm{~K}(\%)$ & 1.06 & 1.51 & 1.86 & 0.26 \\
\hline 10 & $\mathrm{Li}(\mathrm{ppm})$ & 16.4 & 21.5 & 24.9 & 0.2 \\
\hline 11 & $\operatorname{Mg}(\%)$ & 0.283 & 0.599 & 0.906 & 0.52 \\
\hline 12 & $\mathrm{Mn}(\mathrm{ppm})$ & 257 & 398 & 533 & 0.35 \\
\hline 13 & $\mathrm{Na}(\%)$ & 0.52 & 0.815 & 1.1 & 0.36 \\
\hline 14 & $\mathrm{Ni}(\mathrm{ppm})$ & 11.8 & 15 & 18.7 & 0.23 \\
\hline 15 & $\mathrm{~Pb}(\mathrm{ppm})$ & 14.5 & 16.5 & 19.8 & 0.16 \\
\hline 16 & $\mathrm{Se}(\mathrm{ppm})$ & 0.205 & 0.293 & 0.393 & 0.32 \\
\hline 17 & $\mathrm{Sr}(\mathrm{ppm})$ & 77.3 & 148 & 207 & 0.44 \\
\hline 18 & $\mathrm{Ti}(\%)$ & 0.192 & 0.253 & 0.317 & 0.25 \\
\hline 19 & $\mathrm{~V}(\mathrm{ppm})$ & 45.9 & 67.3 & 80.3 & 0.26 \\
\hline 20 & $\mathrm{Y}(\mathrm{ppm})$ & 18.1 & 22.7 & 28.6 & 0.23 \\
\hline 21 & $\mathrm{Zn}(\mathrm{ppm})$ & 36.8 & 51.7 & 65.7 & 0.28 \\
\hline 22 & $\mathrm{Zr}(\mathrm{ppm})$ & 150 & 188.2 & 247 & 0.26 \\
\hline
\end{tabular}

Results and Interpretation

\section{Features of the Geochemical Landscape and Correlations with Known Geology, Climate, and Human Activity}

Table 4 shows the quartiles and the relative quartile deviations of smoothed data for each element from the whole area. The geochemical maps are presented in figures 3-24. 


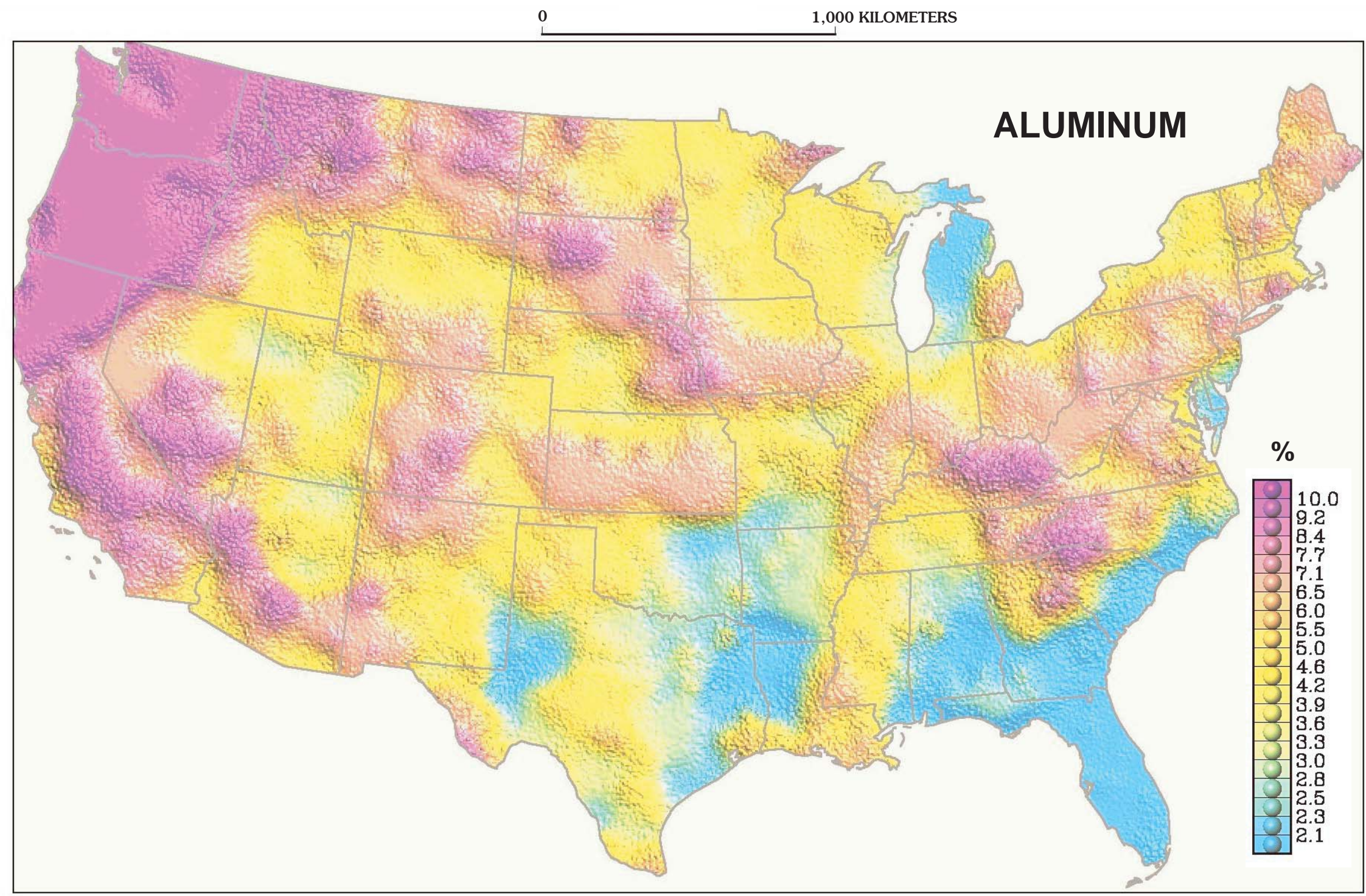

Figure 3. Colored surface map of Al distribution in soils and other surficial materials of the conterminous United States. 
0

1,000 KILOMETERS

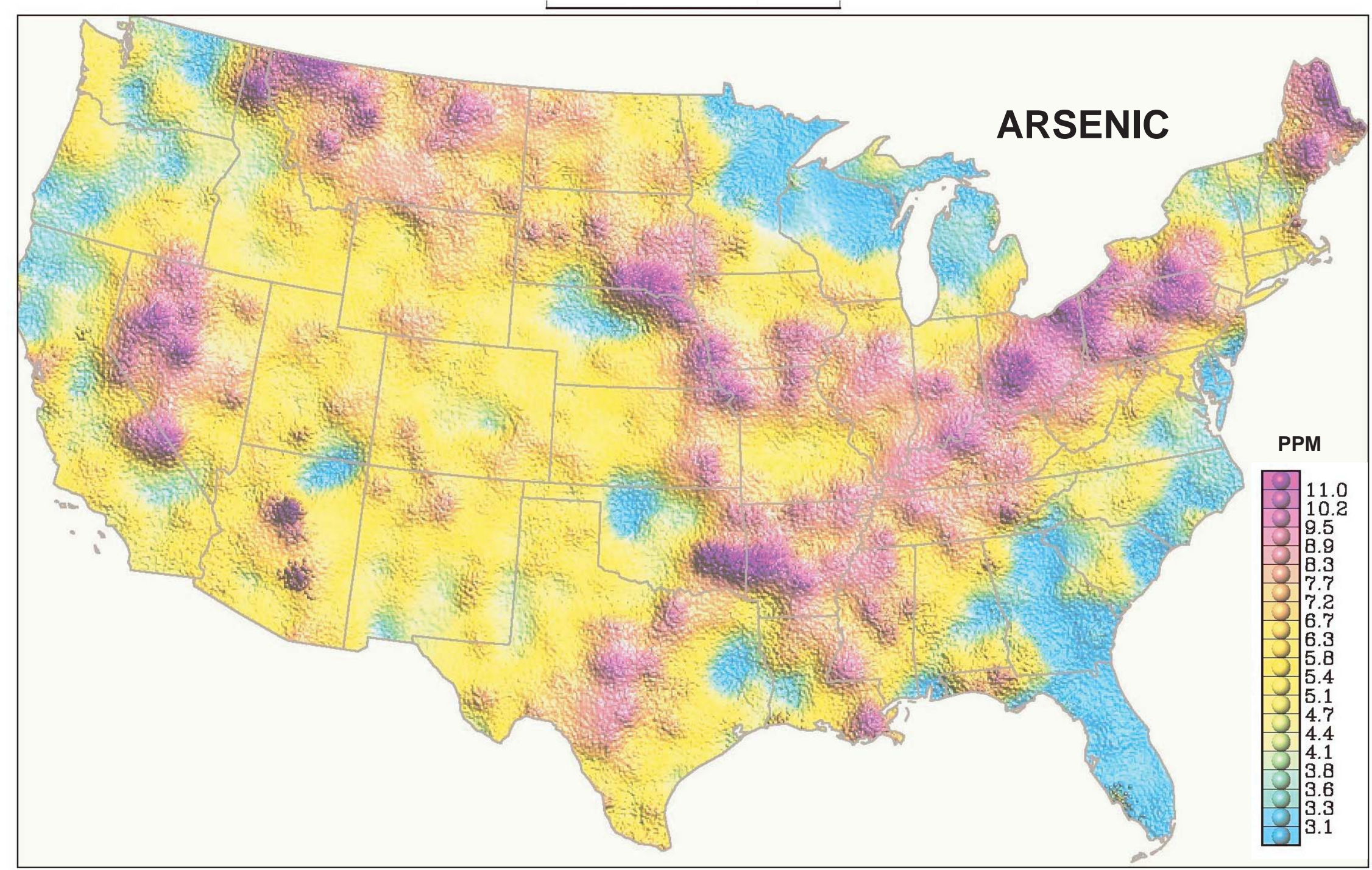

Figure 4. Colored surface map of As distribution in soils and other surficial materials of the conterminous United States. 
1,000 KILOMETERS

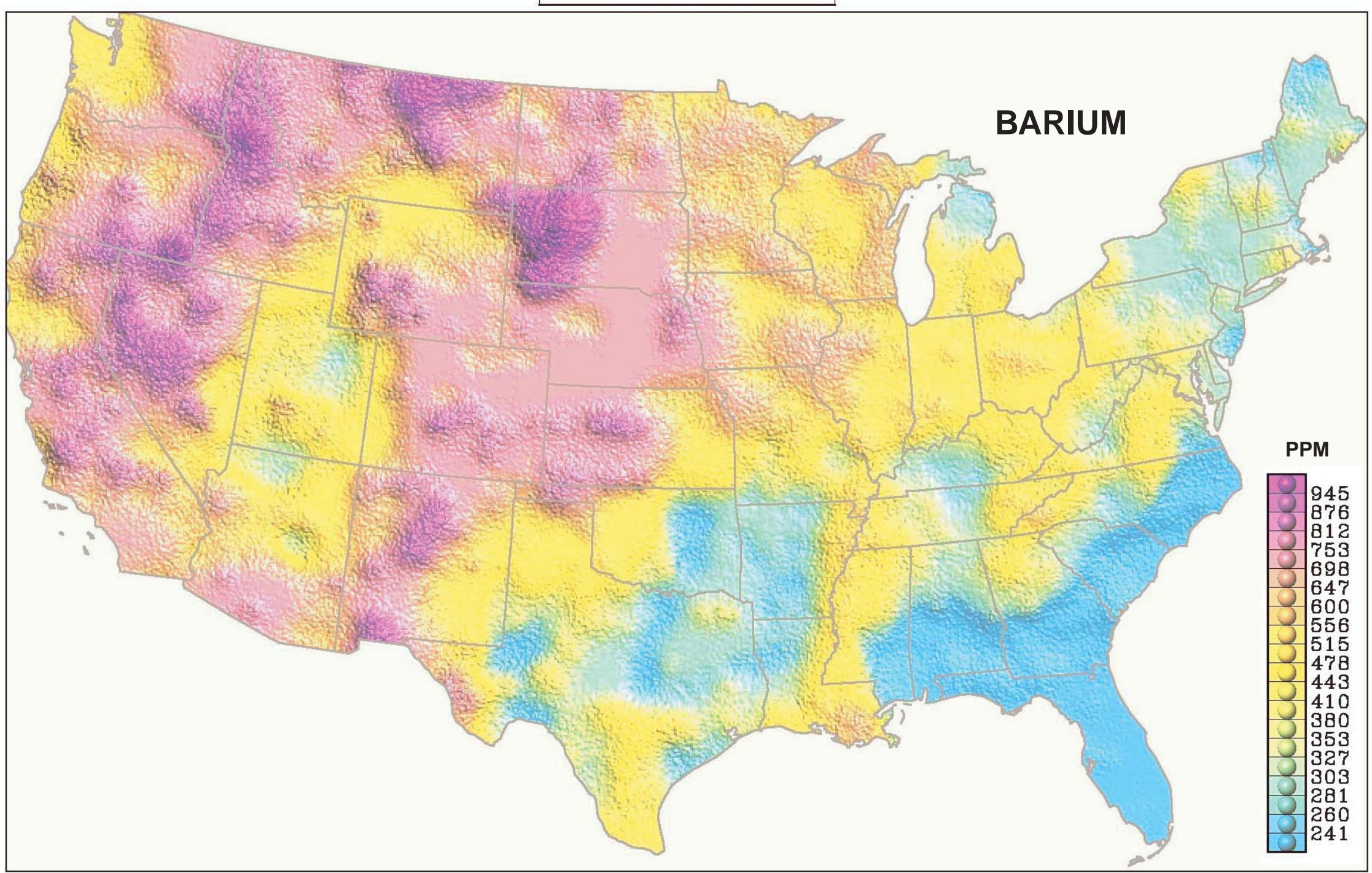

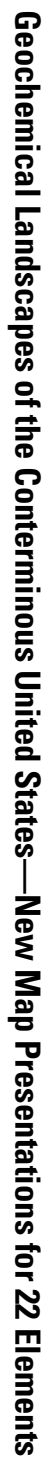

Figure 5. Colored surface map of Ba distribution in soils and other surficial materials of the conterminous United States. 
$0 \quad 1,000$ KILOMETERS

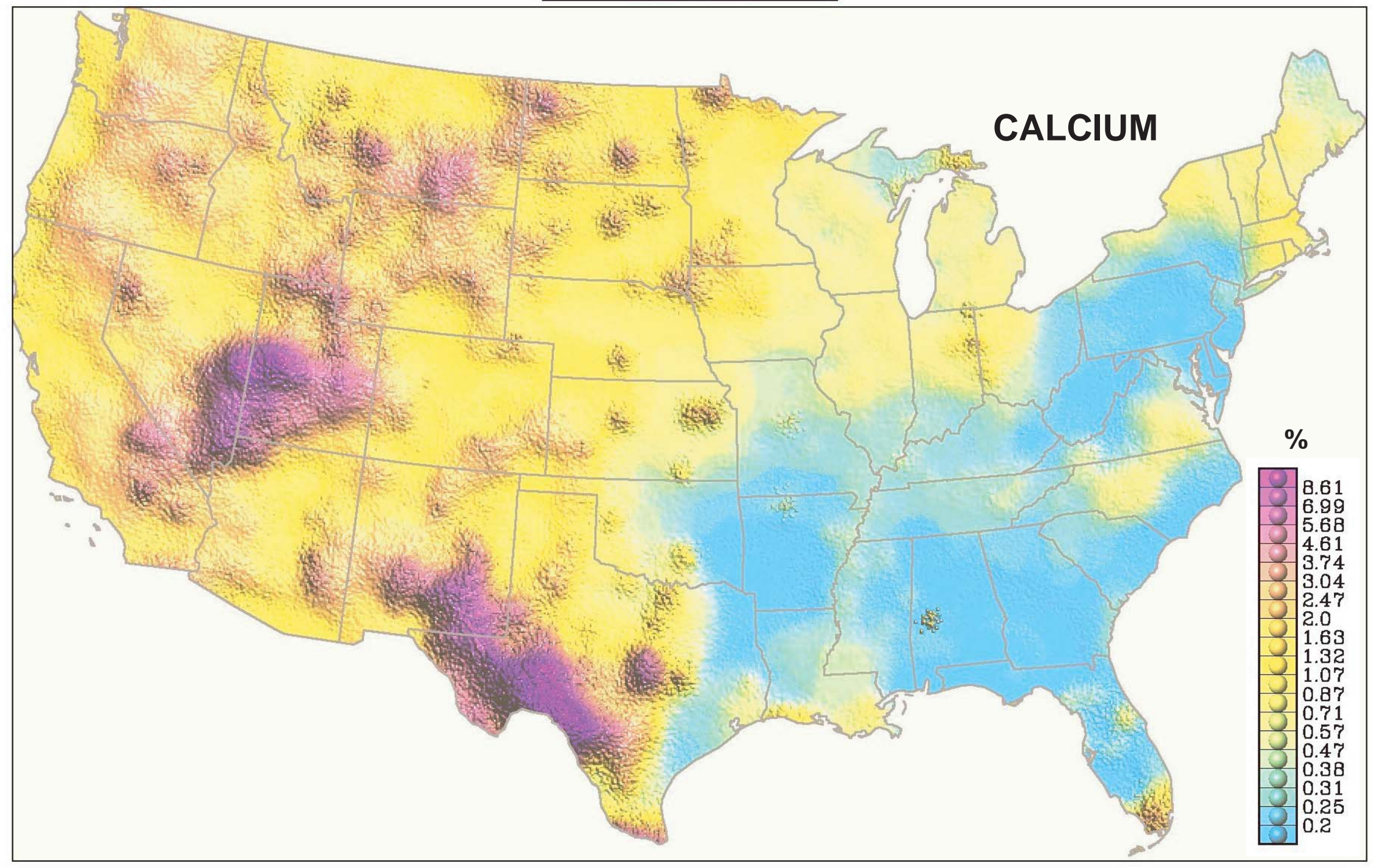

Figure 6. Colored surface map of Ca distribution in soils and other surficial materials of the conterminous United States. 
1,000 KILOMETERS

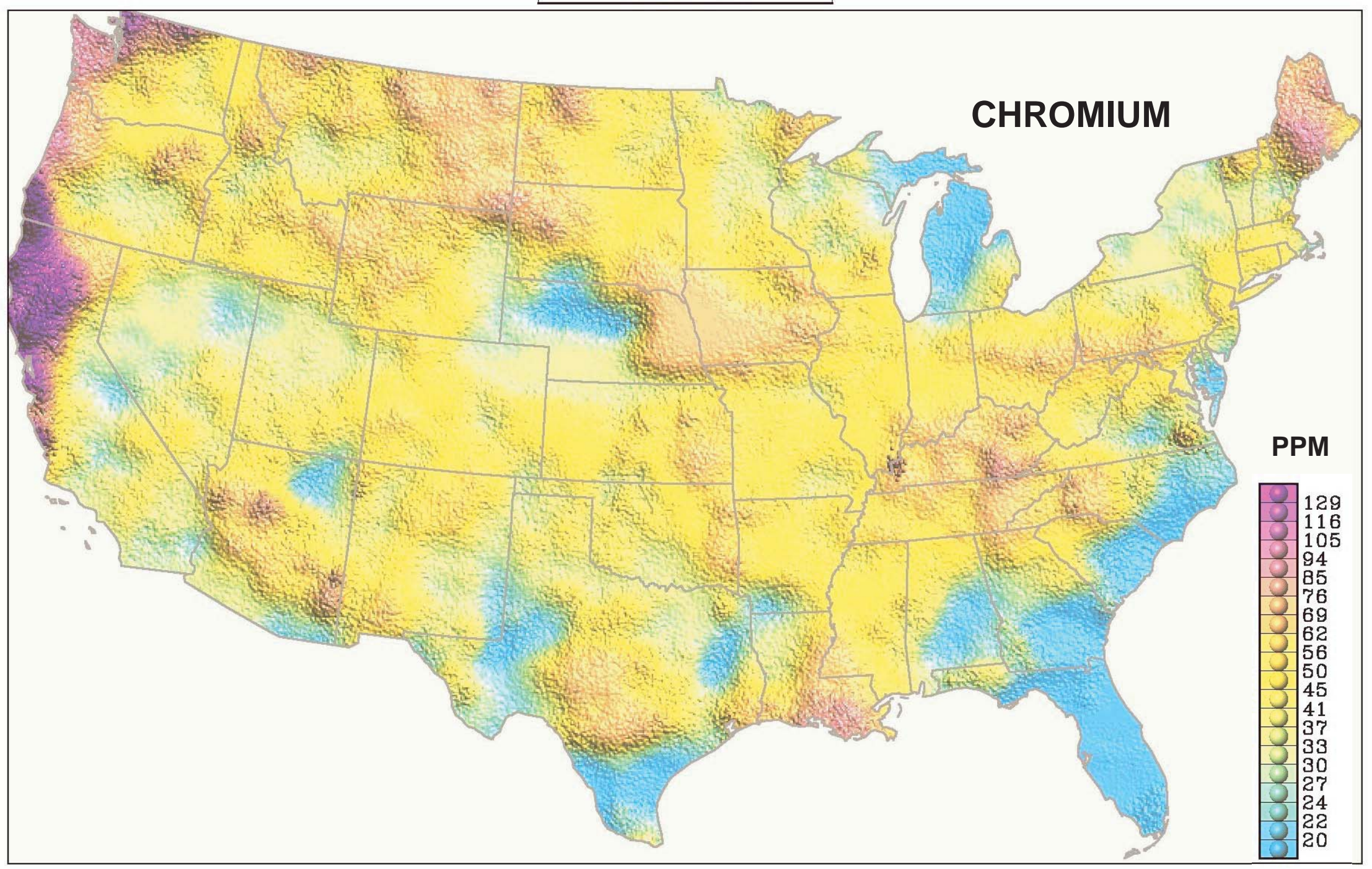

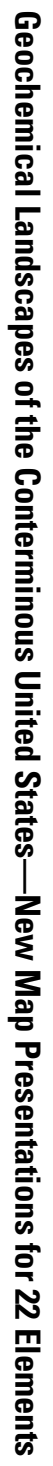

Figure 7. Colored surface map of $\mathrm{Cr}$ distribution in soils and other surficial materials of the conterminous United States. 
0

1,000 KILOMETERS

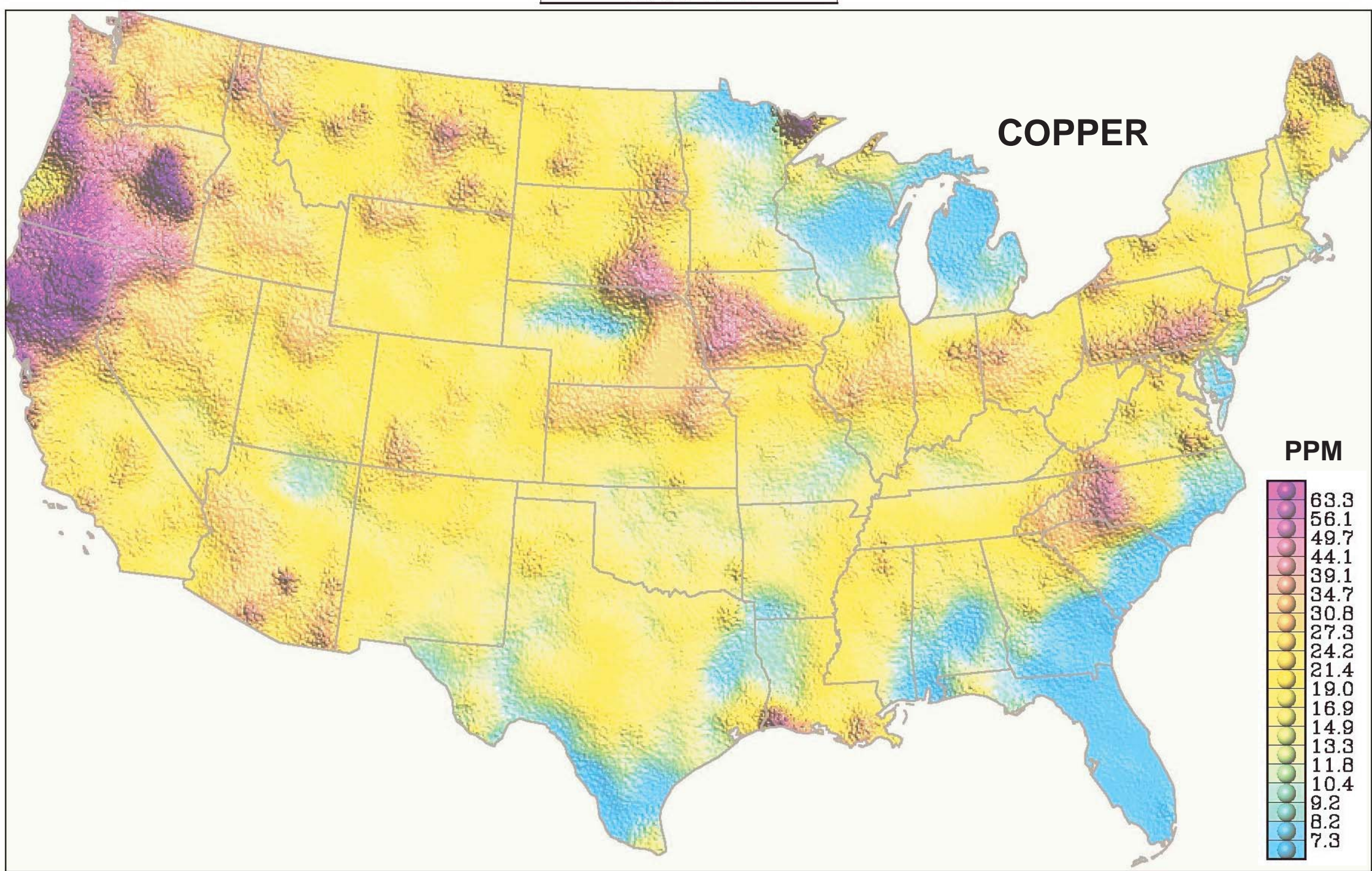

Figure 8. Colored surface map of Cu distribution in soils and other surficial materials of the conterminous United States. 
1,000 KILOMETERS

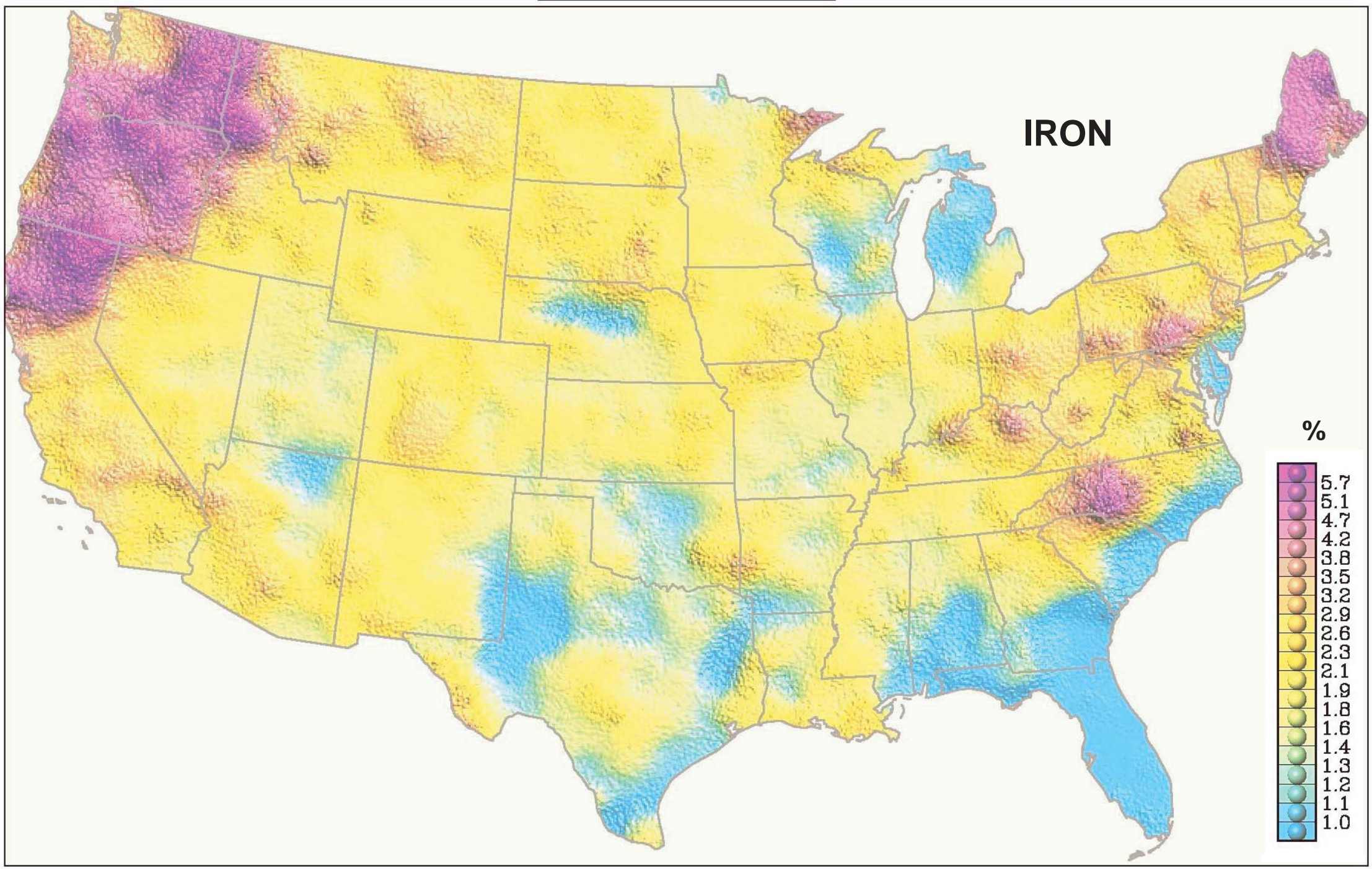

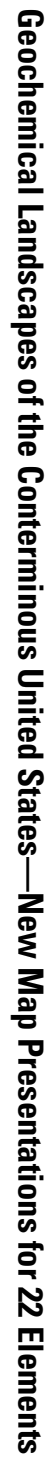

Figure 9. Colored surface map of Fe distribution in soils and other surficial materials of the conterminous United States. 
1,000 KILOMETERS

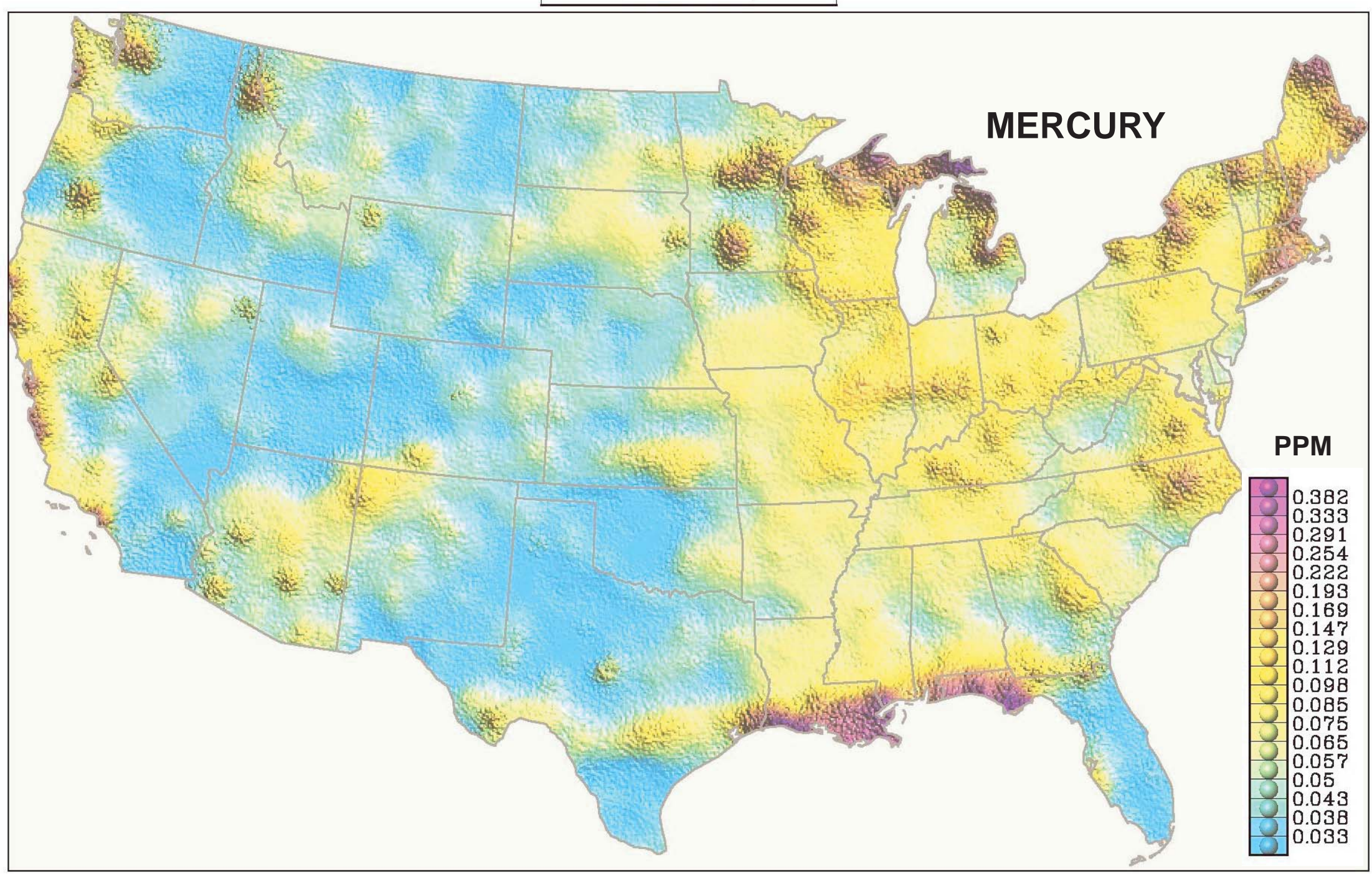

Figure 10. Colored surface map of Hg distribution in soils and other surficial materials of the conterminous United States. 
1,000 KILOMETERS

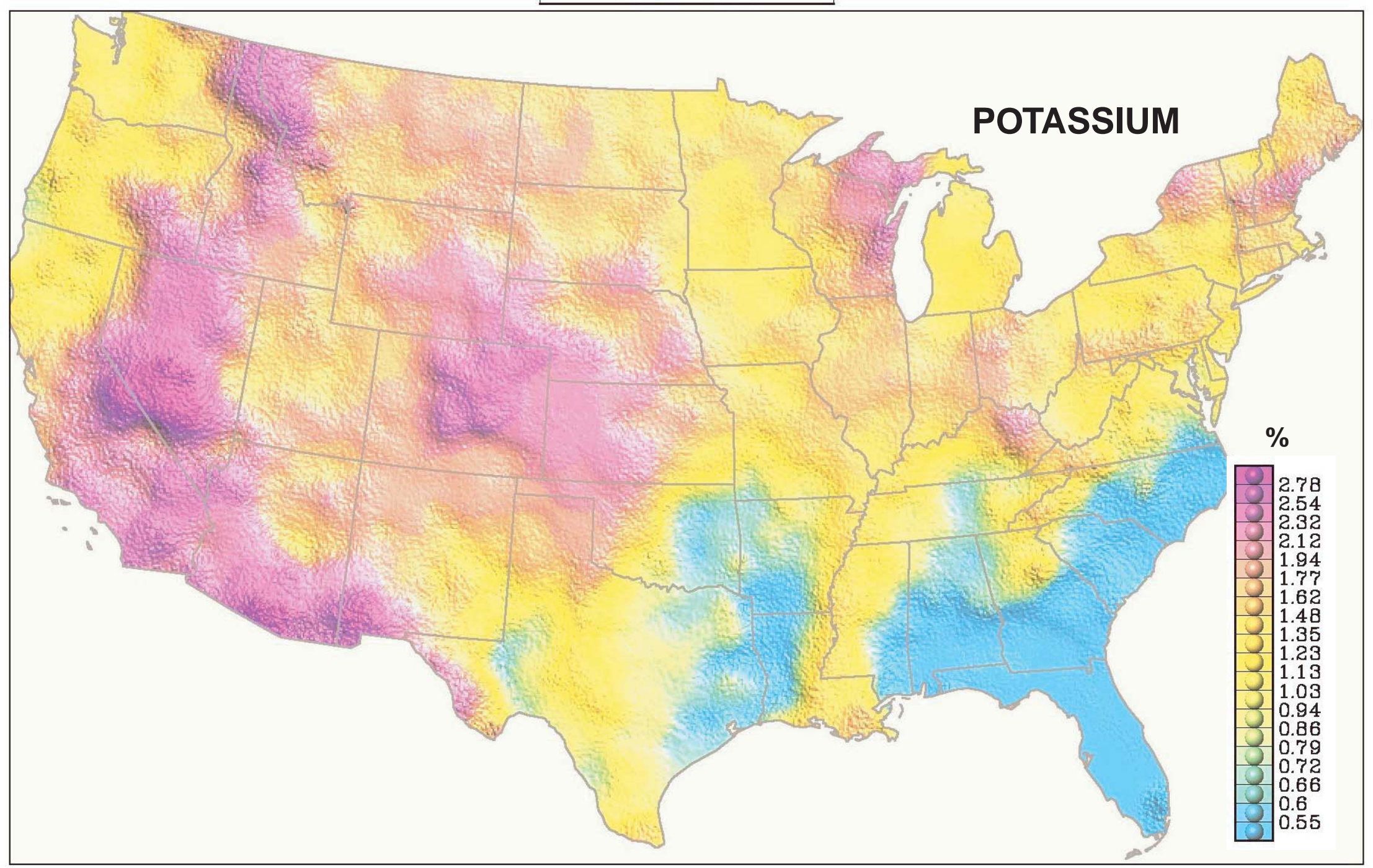

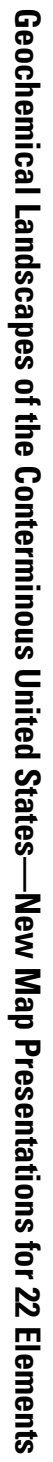

Figure 11. Colored surface map of $\mathrm{K}$ distribution in soils and other surficial materials of the conterminous United States. 
0

1,000 KILOMETERS

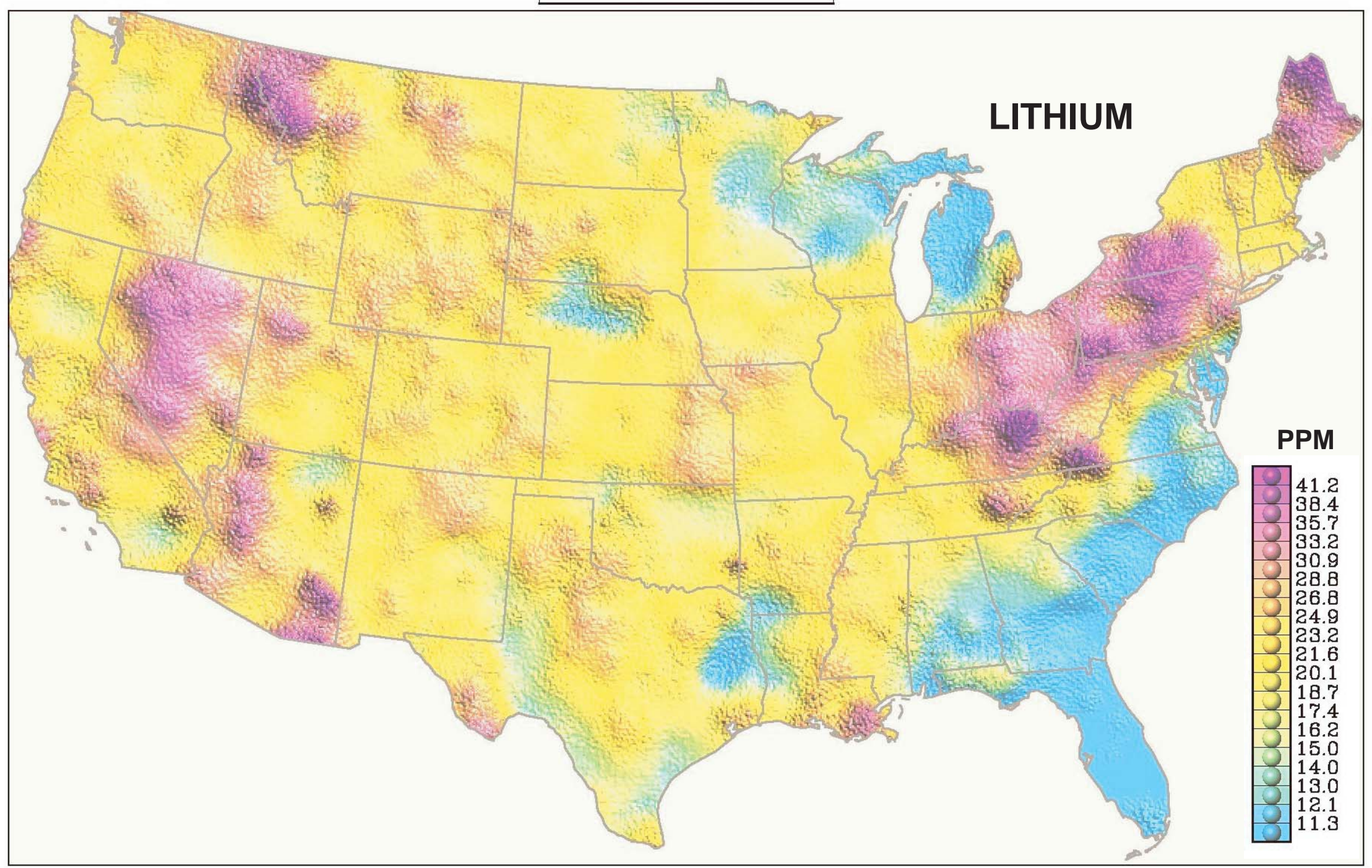

Figure 12. Colored surface map of Li distribution in soils and other surficial materials of the conterminous United States. 
1,000 KILOMETERS

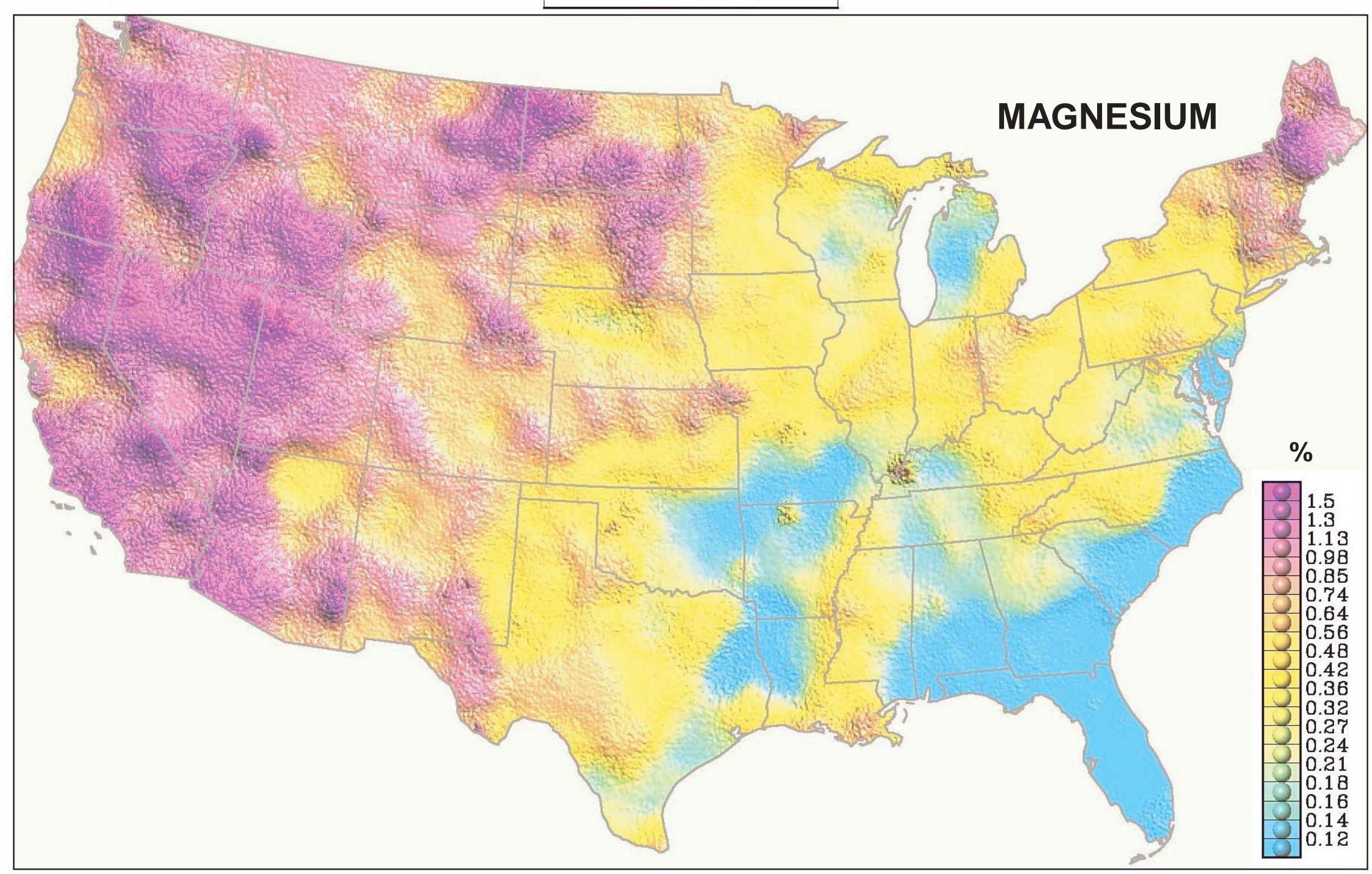




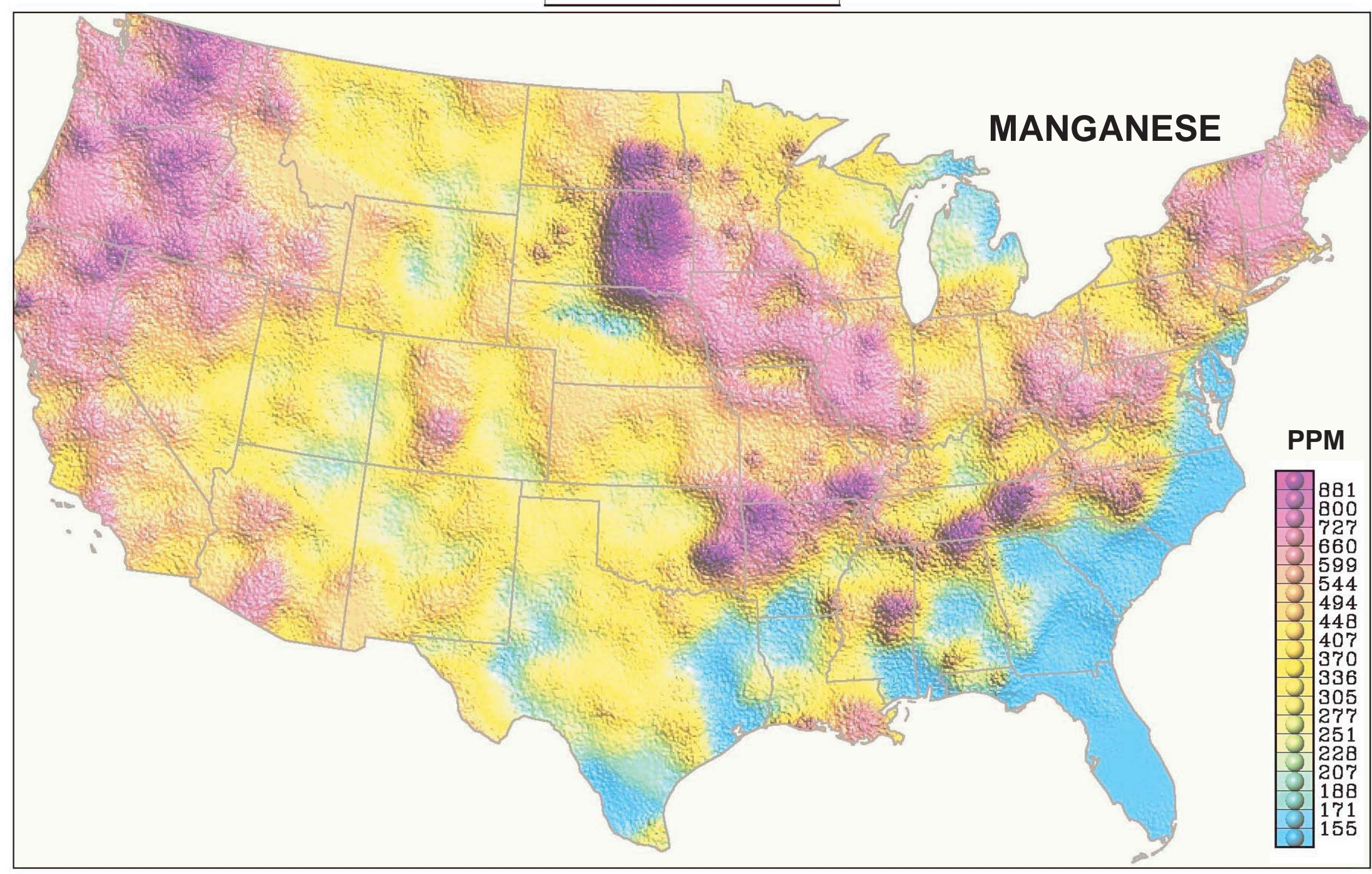

Figure 14. Colored surface map of Mn distribution in soils and other surficial materials of the conterminous United States. 
1,000 KILOMETERS

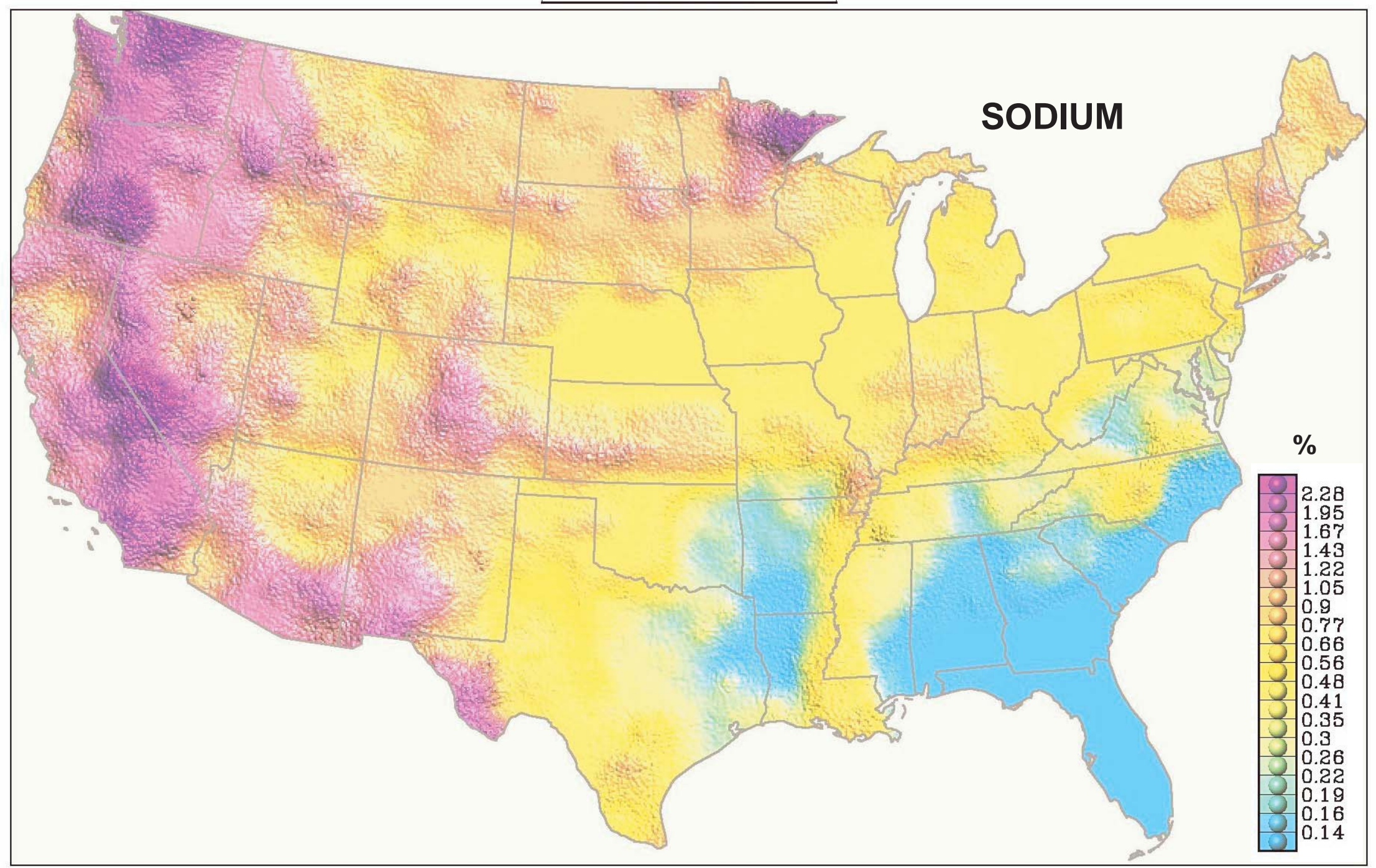

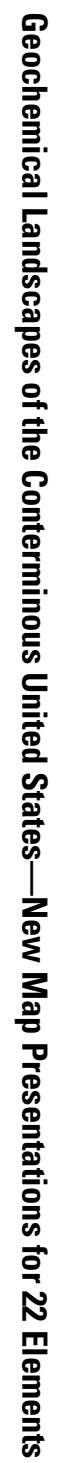

Figure 15. Colored surface map of Na distribution in soils and other surficial materials of the conterminous United States. 
1,000 KILOMETERS

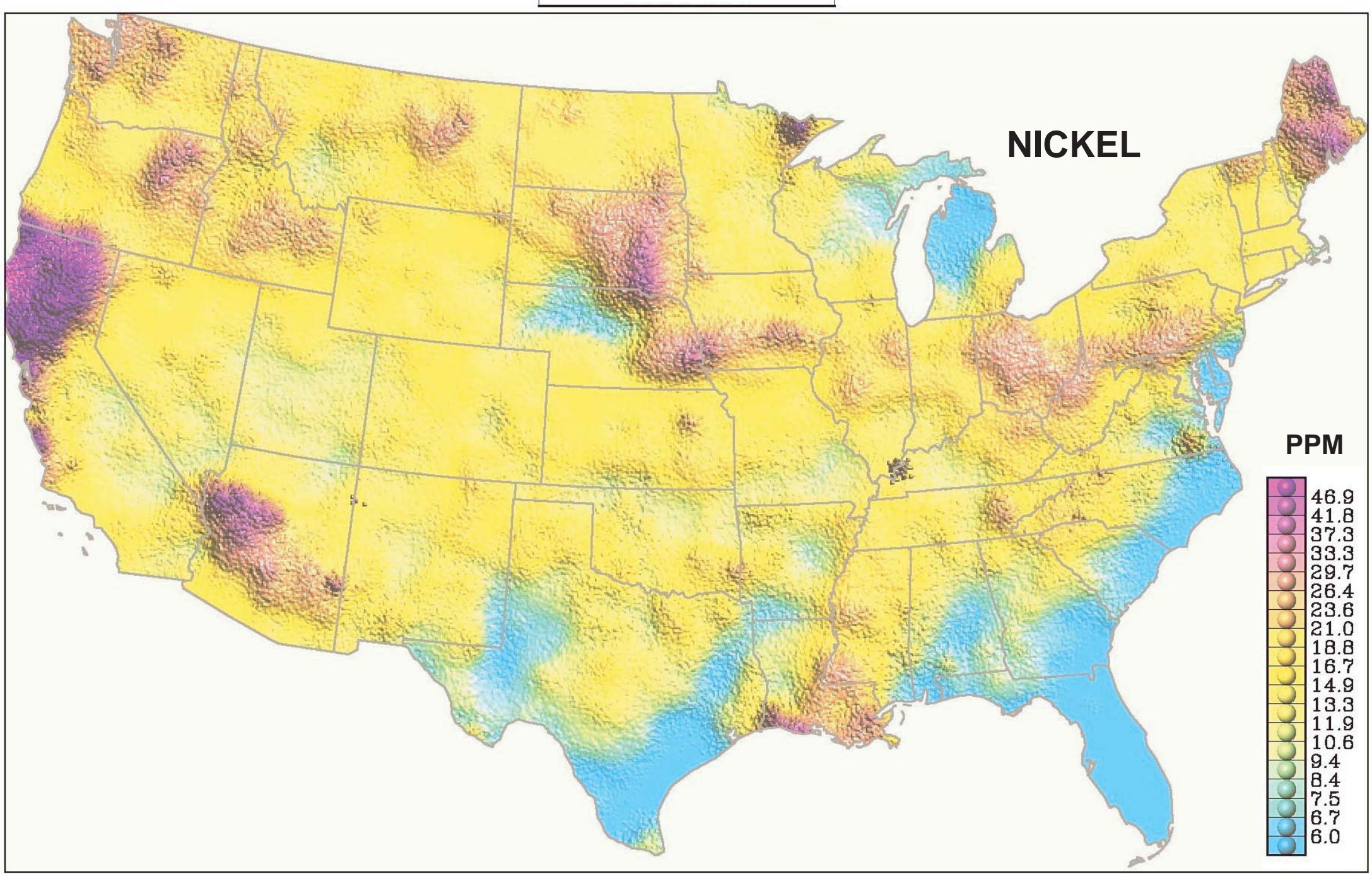

Figure 16. Colored surface map of Ni distribution in soils and other surficial materials of the conterminous United States. 
1,000 KILOMETERS

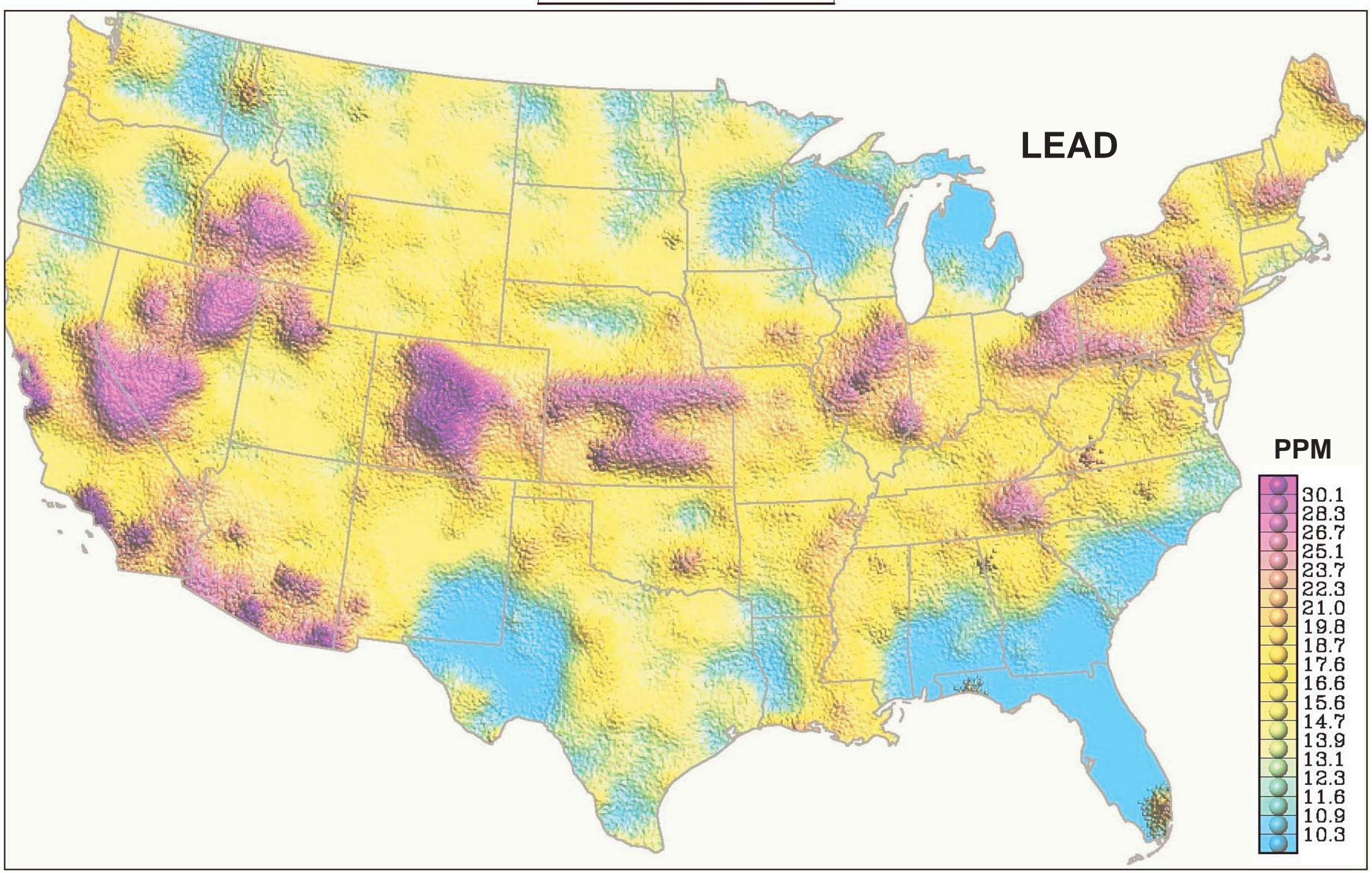

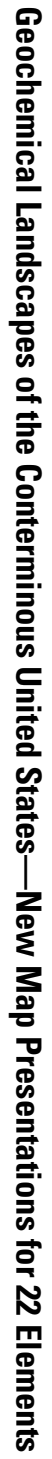

Figure 17. Colored surface map of $\mathrm{Pb}$ distribution in soils and other surficial materials of the conterminous United States. 
0

1,000 KILOMETERS

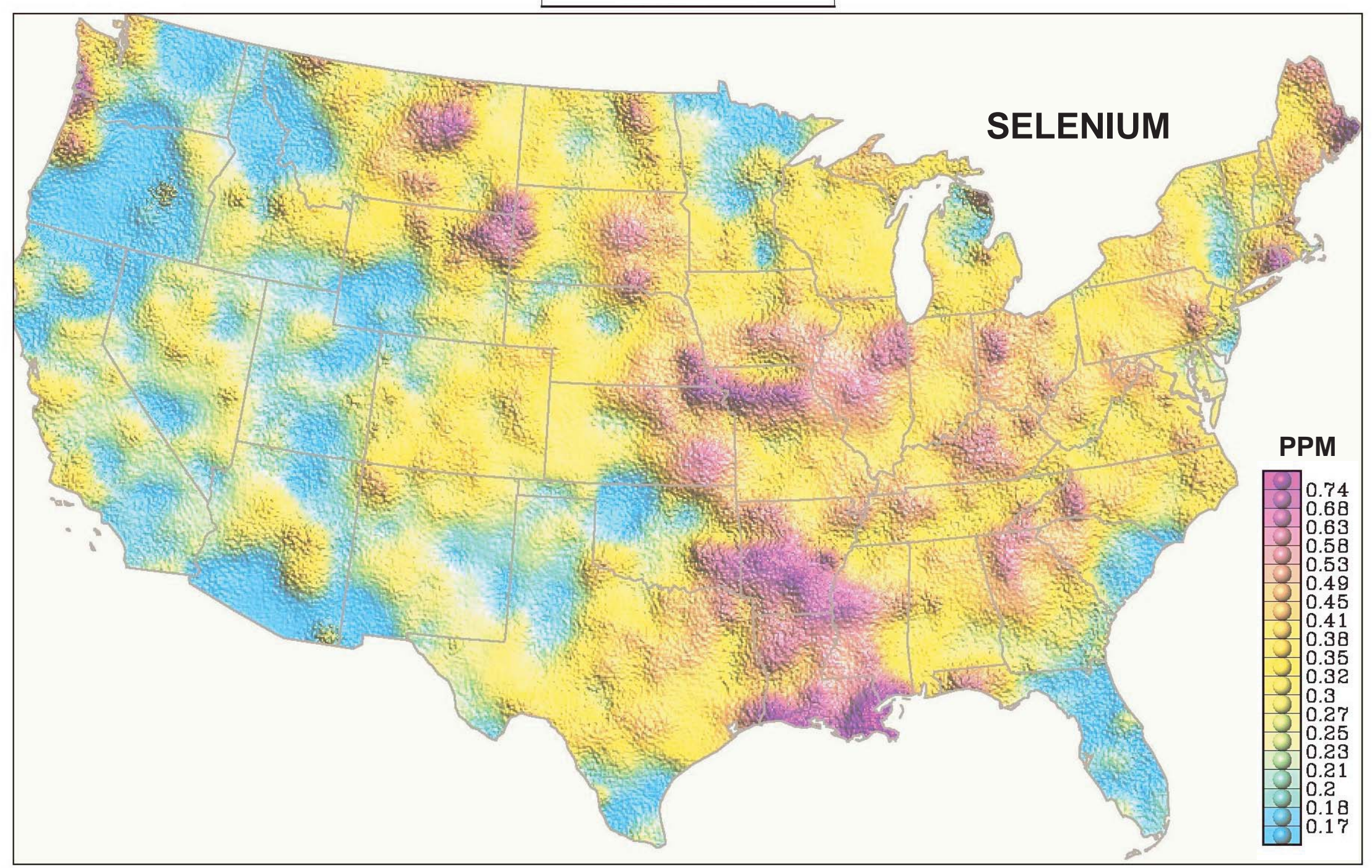

Figure 18. Colored surface map of Se distribution in soils and other surficial materials of the conterminous United States. 
1,000 KILOMETERS

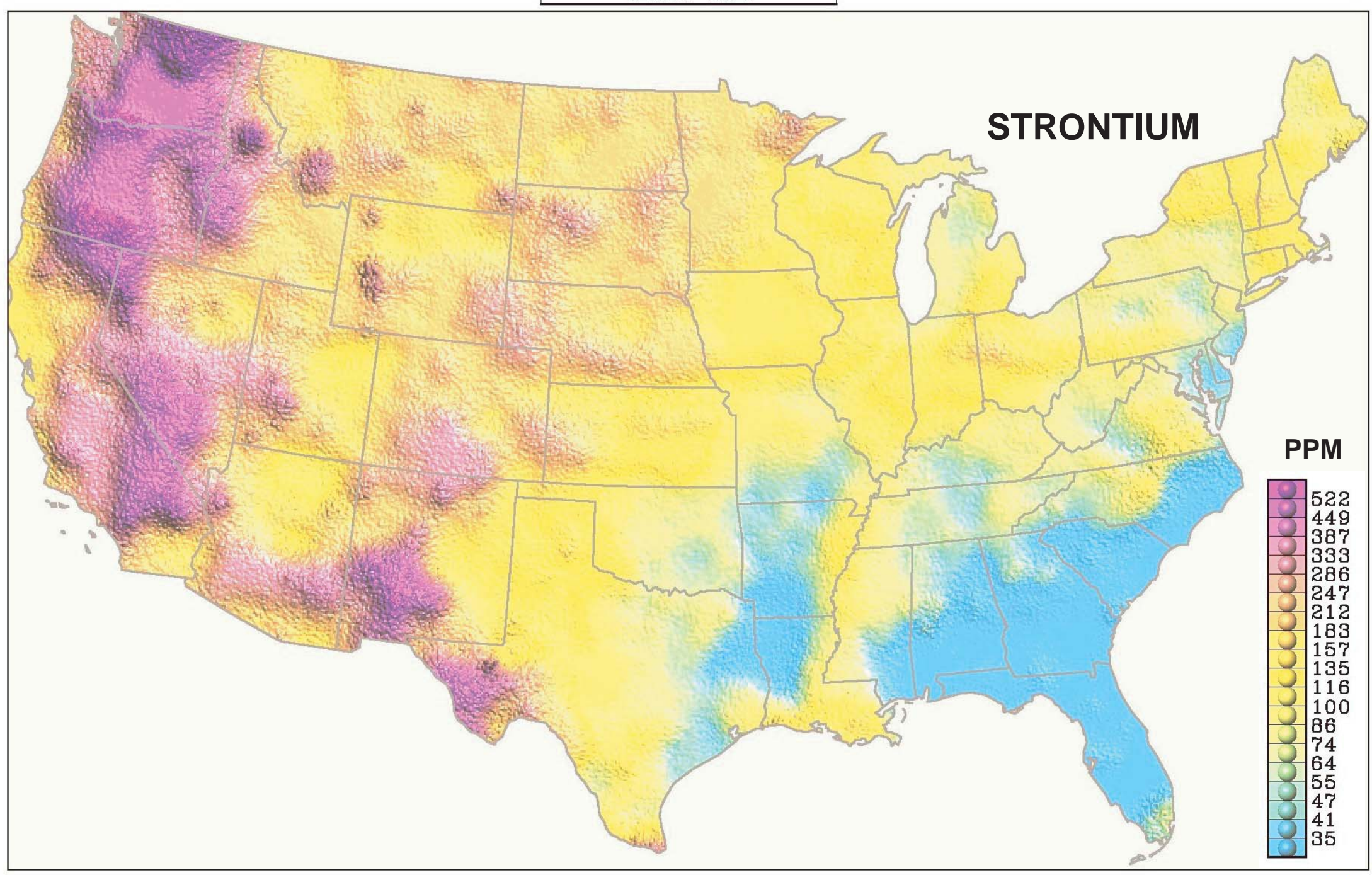

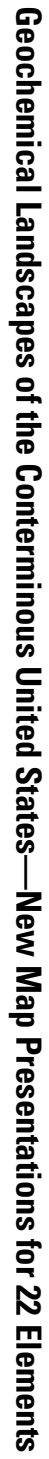

Figure 19. Colored surface map of Sr distribution in soils and other surficial materials of the conterminous United States. 
0

1,000 KILOMETERS

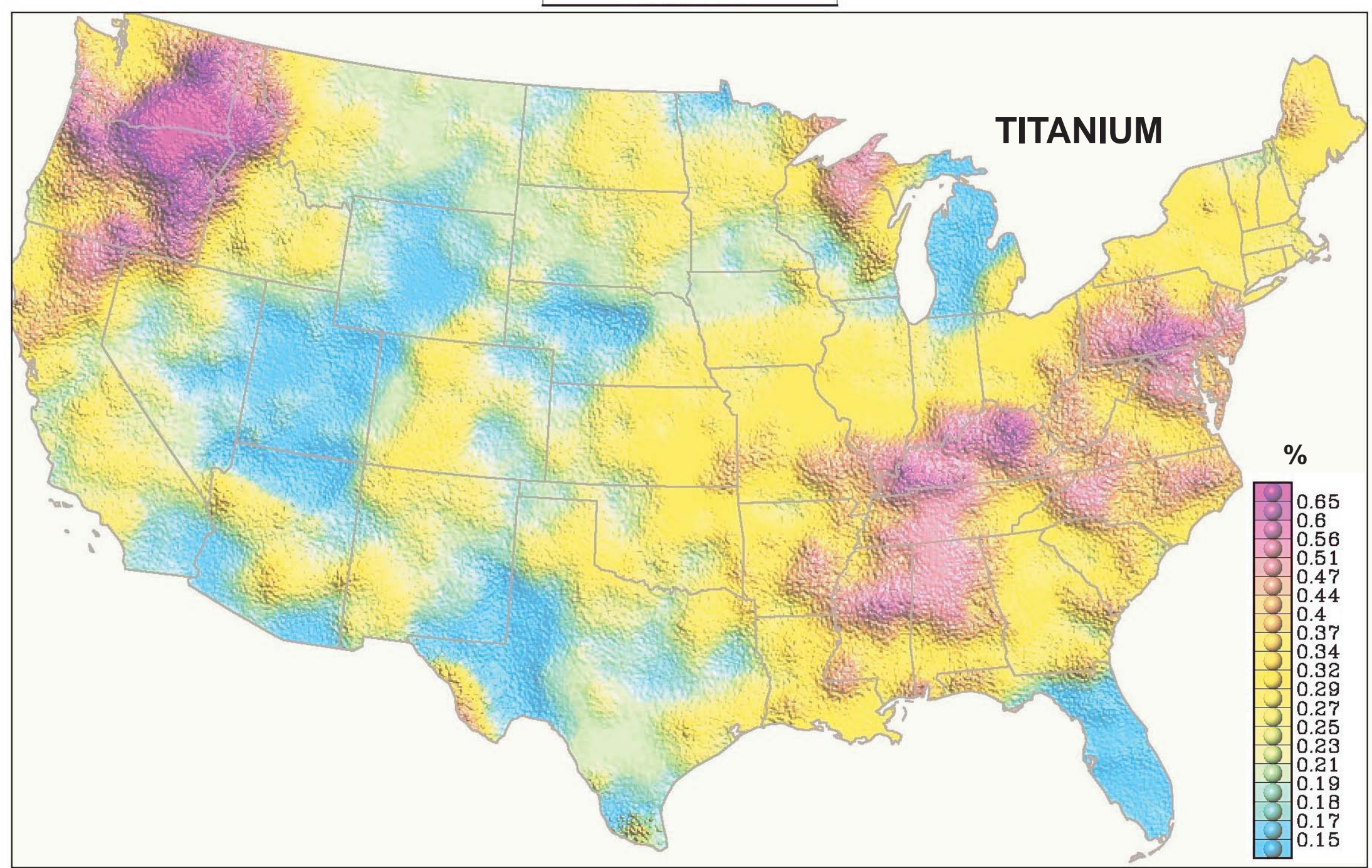

Figure 20. Colored surface map of Ti distribution in soils and other surficial materials of the conterminous United States. 


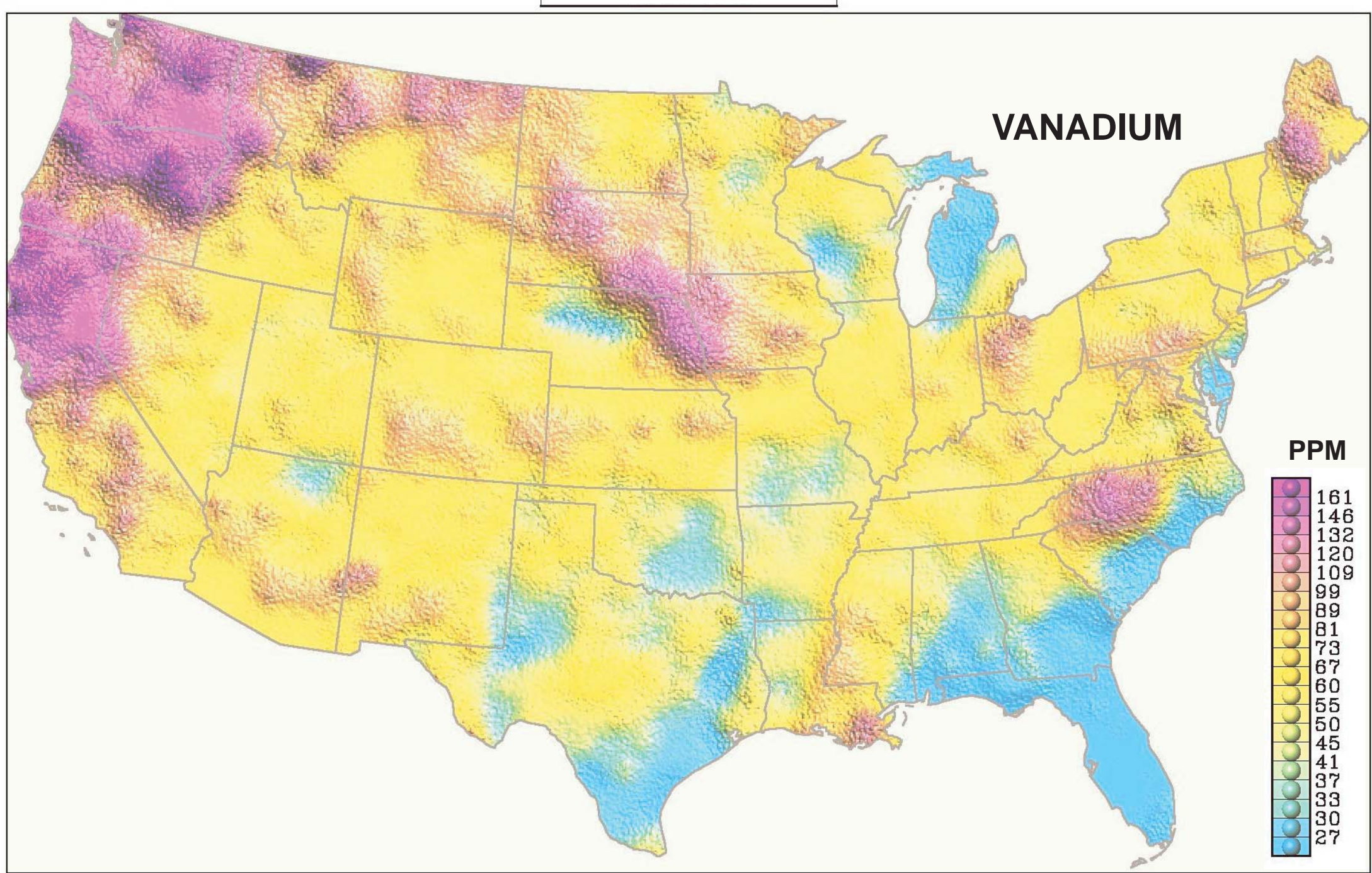

Figure 21. Colored surface map of $\mathrm{V}$ distribution in soils and other surficial materials of the conterminous United States. 
0

1,000 KILOMETERS

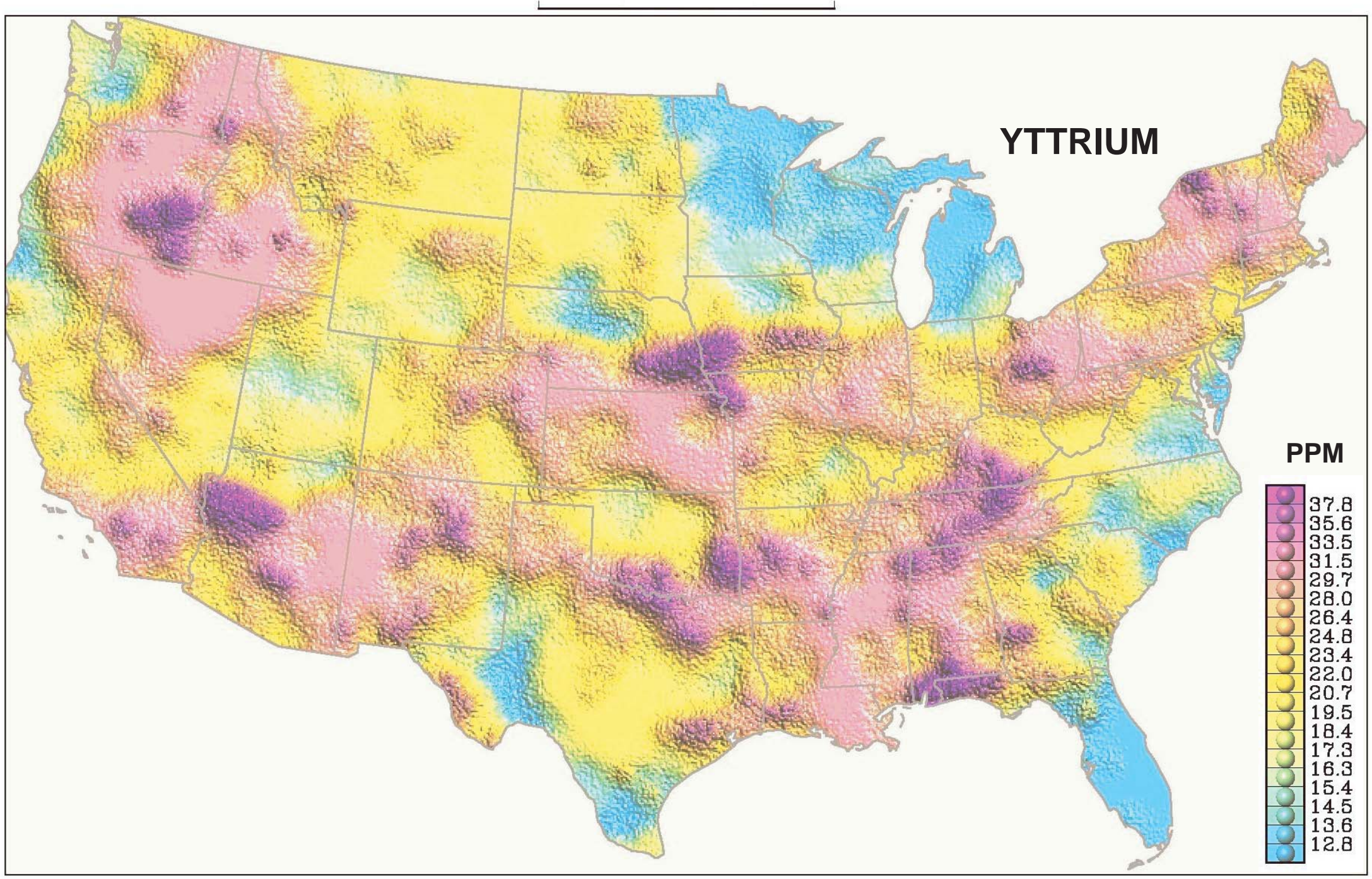

Figure 22. Colored surface map of $Y$ distribution in soils and other surficial materials of the conterminous United States. 


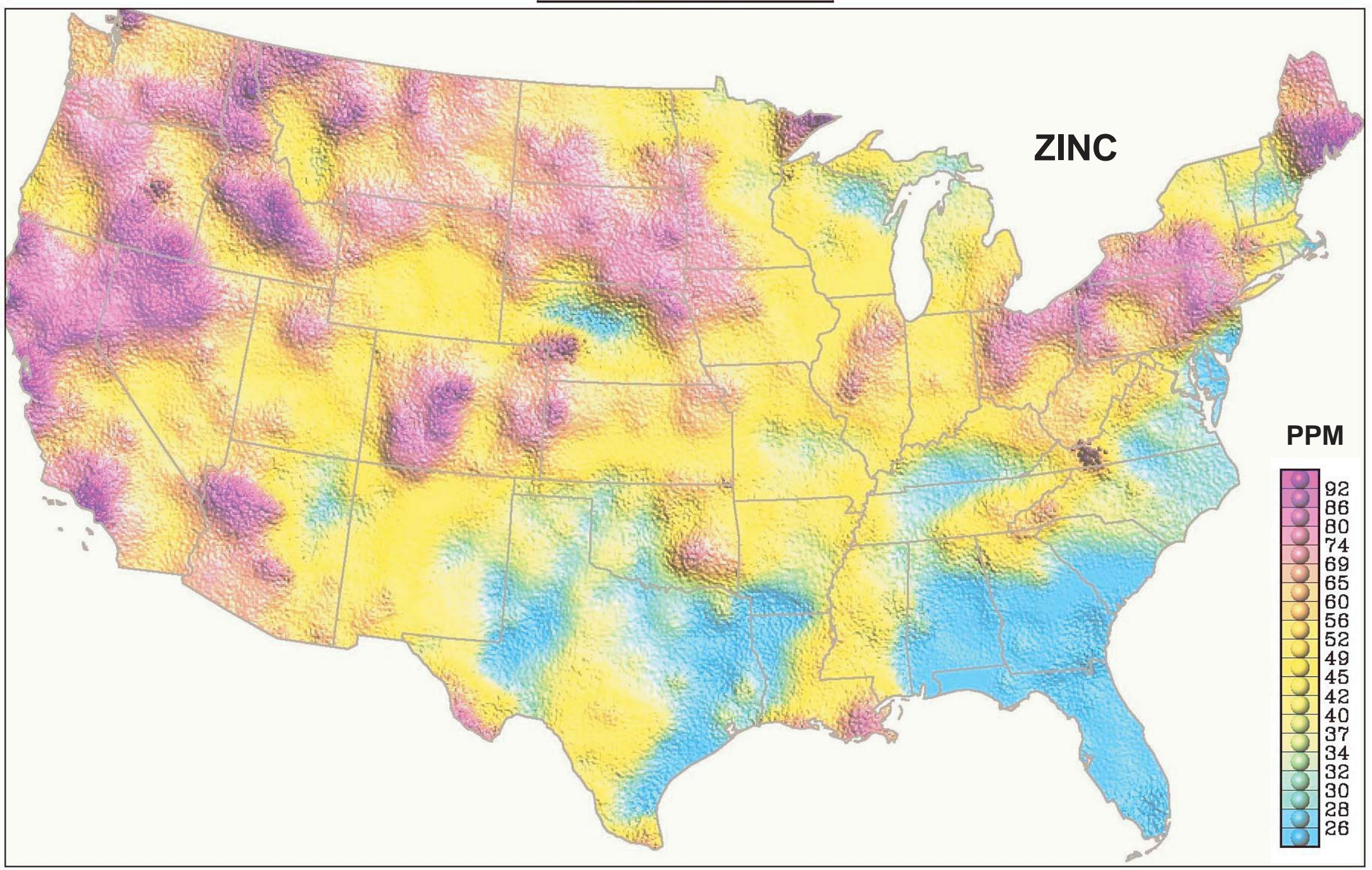




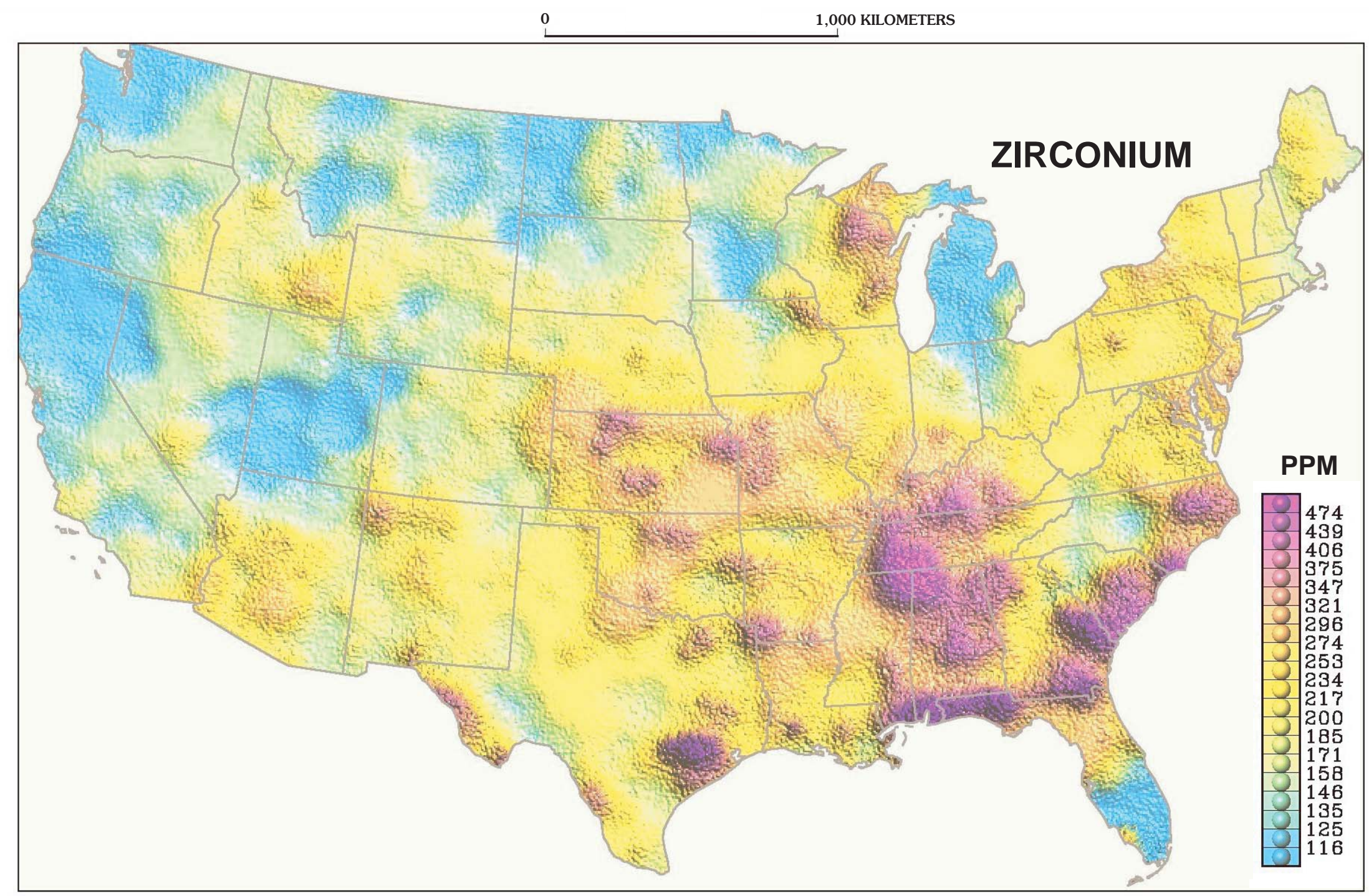

Figure 24. Colored surface map of Zr distribution in soils and other surficial materials of the conterminous United States. 


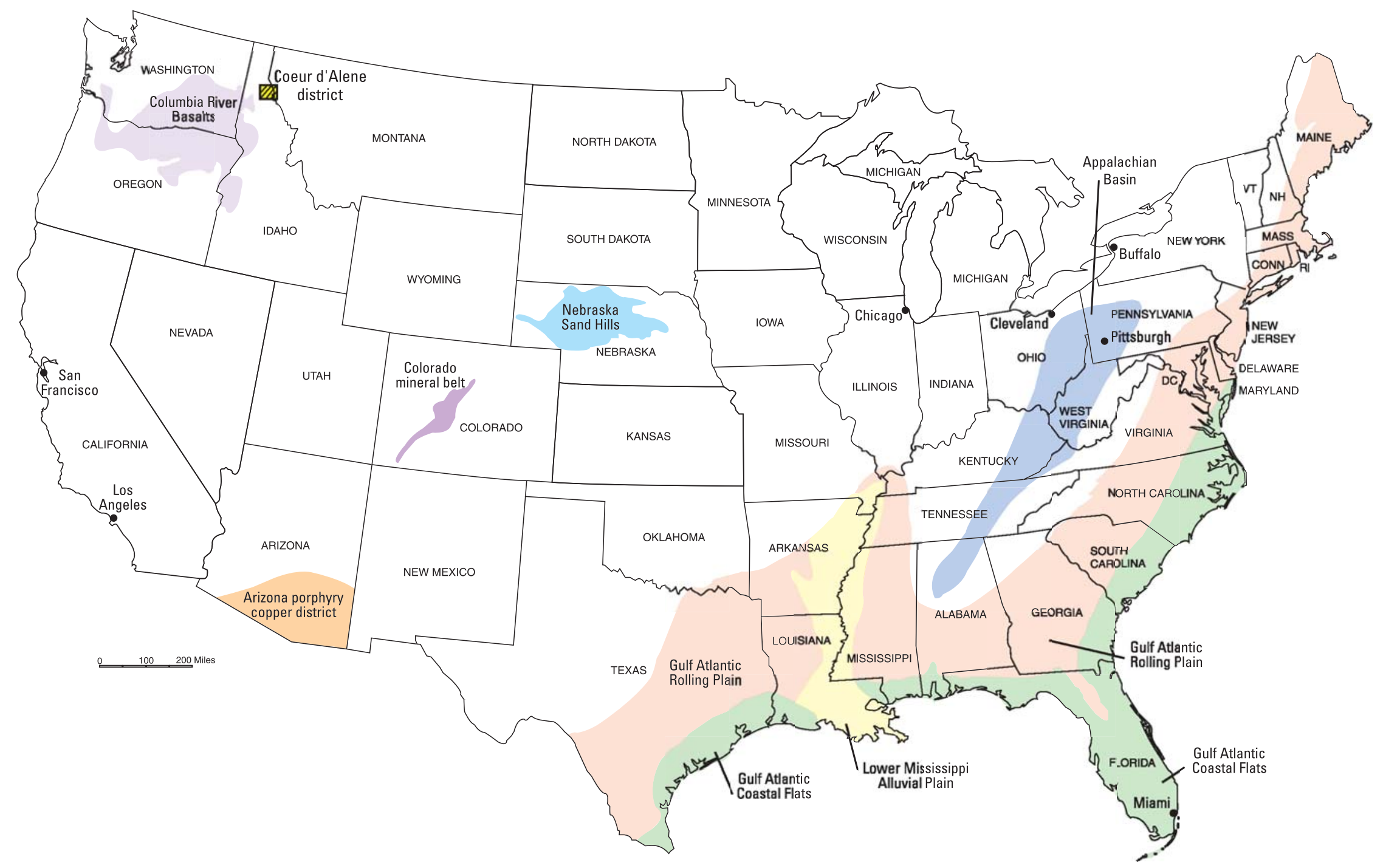

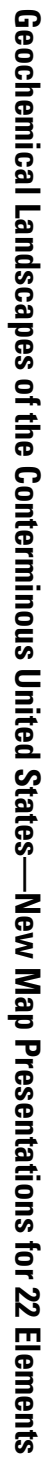

Figure 25. Map of conterminous United States showing approximate location of selected physiographic and geologic features. 
A number of broad geochemical dispersion patterns are obtained for both major and trace elements (figs. 3-24). Some of these patterns were previously described by Shacklette and Boerngen (1984), and further comments are found in the following discussion. The discussion and interpretation of the geochemical patterns frequently necessitates reference to physiographic and geologic features of the conterminous United States. Figure 25 shows the approximate location of these features.

1. The largest scale regional pattern observed on the maps is formed by elements such as $\mathrm{Ba}, \mathrm{Ca}, \mathrm{K}, \mathrm{Mg}, \mathrm{Na}$, and Sr. All these elements show significantly higher concentrations in the western part of United States than in the eastern part. This main pattern likely represents a complex interaction of factors such as bedrock composition, topography, climate, soil development, and vegetation. It is difficult to judge the contribution for each factor.

Shacklette and Boerngen (1984) point out that the abundances of $\mathrm{Ba}, \mathrm{Ca}, \mathrm{Mg}, \mathrm{K}, \mathrm{Na}$, and $\mathrm{Sr}$ are markedly different on either side of a line extending from western Minnesota southward through east-central Texas, which marks the approximate boundary between classes of moist-to-wet soils in the Eastern United States and dry soils of the West as mapped by the U.S. Soil Conservation Service (1969). Thus, the effect of climate on soil formation is probably a major factor in the development of these regional geochemical patterns.

2. Another striking feature is the low concentration of many elements in portions of the Gulf-Atlantic Coastal Flats and the Gulf-Atlantic Rolling Plain as defined by Hammond (1964). This area includes the State of Florida and portions of North Carolina, South Carolina, Georgia, Alabama, Mississippi, and Texas. This feature is likely due to a combination of the abundance of quartz sand in surficial material and the wet climate, which causes leaching of many elements from the upper soil horizons. The only exceptions among the mapped elements to this trend of low concentration are $\mathrm{Zr}$ and $\mathrm{Y}$. These elements show relatively high concentrations along the Gulf-Atlantic Coastal Flats of northern Florida, southern Alabama and Mississippi, and eastern South and North Carolina. This trend is believed to reflect the placer accumulation of heavy minerals, such as zircon and xenotime, within sandy soils and their resistance to weathering.

3. The feature described in no. 2 above is interrupted by the alluvial plain of the Mississippi River. This is best seen in the distribution of $\mathrm{Al}, \mathrm{Ba}, \mathrm{K}, \mathrm{Mg}, \mathrm{Na}, \mathrm{Sr}$, and $\mathrm{Zn}$. It appears that the flood plains of the Mississippi River system contain long-transported sediments with a composition more typical for the West (no. 1 above) than for the Southeast (no. 2 above).

4. Northern California and southern Oregon show high levels of $\mathrm{Cu}, \mathrm{Cr}$, and $\mathrm{Ni}$. This is consistent with the presence of ultramafic rocks in this area (Jennings, 1977; Walker and MacLeod, 1991).

5. The area in north-central Nebraska with low concentrations of $\mathrm{As}, \mathrm{Cu}, \mathrm{Cr}, \mathrm{Fe}, \mathrm{Li}, \mathrm{Mg}, \mathrm{Mn}, \mathrm{Ni}, \mathrm{Pb}, \mathrm{Ti}, \mathrm{V}$, $\mathrm{Y}$, and $\mathrm{Zn}$ corresponds to the Nebraska Sand Hills, the largest dune field in the Western Hemisphere (Ahlbrandt and Fryberger, 1980).

6. The area of central Colorado containing elevated concentrations of $\mathrm{Pb}$ and $\mathrm{Zn}$ corresponds to the Colorado mineral belt, a region of historic precious- and basemetal mining (Tweto and Sims, 1963). This zone of increased $\mathrm{Pb}$ and $\mathrm{Zn}$ concentration also shows up on a geochemical map of Colorado based on data from stream sediments collected during the National Uranium Resource Evaluation (NURE) program (Plumlee and others, 1993; Grossman, 1998).

7. High concentrations of $\mathrm{As}, \mathrm{Cu}, \mathrm{Hg}, \mathrm{Pb}$, and $\mathrm{Zn}$ in northern Idaho corresponds to the Coeur d'Alene mining district, a region of historic base- and preciousmetal mining (Ransome, 1908).

8. The southern Arizona porphyry copper province (Titley, 1982) is shown by increased abundance of $\mathrm{Cu}$ and $\mathrm{Pb}$.

9. Immediately to the north of the Arizona copper province is a region of increased abundance of $\mathrm{Cr}, \mathrm{Ni}$, and V. This area seems to correspond to a belt of Precambrian rocks that include diabase, diorite, gabbro, pyroxenite, and basalt as shown by Wilson and others (1969).

10. The area of eastern Oregon and Washington showing high $\mathrm{Fe}, \mathrm{Mg}, \mathrm{V}$, and Ti coincides with exposures of the Columbia River Basalt Group (Huntting and others, 1961; Swanson and others, 1979; Walker and MacLeod, 1991).

11. The Ca map shows two prominent highs-one extending from southern Texas, just east of the Big Bend area, into southeastern New Mexico and the other in western Utah and eastern Nevada. The area of high Ca in southern Texas and southeastern New Mexico shows close correspondence to outcrops of Lower Cretaceous and Permian limestones and Quaternary deposits derived from these limestones (Geologic Atlas of Texas, 1977, 1981, 1982; Dane and Bachman, 1965). The area in western Utah and eastern Nevada contains numerous exposures of Paleozoic limestones exposed by basinand-range faulting (Stewart and Carlson, 1978; Hintze, 1980).

12. A slight increase in $\mathrm{Pb}$ abundance is noted in the vicinity of the cities of Cleveland, Ohio; Miami, Fla.; Buffalo, N.Y.; Pittsburgh, Pa.; Chicago, Ill.; San Francisco, Calif.; and Los Angeles, Calif. This may reflect an anthropogenic component of the geochemical landscape from industrial pollution and automobile exhaust.

13. The distribution of $\mathrm{Hg}$ shows generally higher concentrations in the Eastern than in the Western United 
States. Specific areas with relatively high $\mathrm{Hg}$ concentrations are seen in the South along the coast of Louisiana, Mississippi, Alabama, and the Florida panhandle, and in the North along the coasts of Lake Michigan, Lake Superior, and Lake Huron. These features may be attributed to high contents of organic matter in samples from these coastal areas.

14. The pattern of elevated As concentration from western Pennsylvania through West Virginia, Kentucky, and Tennessee coincides, at least in part, with the Appalachian Basin, which produces high-arsenic coal, and with the distribution of power plants that burn the coal (Goldhaber and others, 2000).

These 14 examples are only a selection of geochemical patterns that can be related to known natural features or associated with anthropogenic pollution. Other observed patterns have no obvious explanation; for example, the higher abundance of Se in the Eastern United States as compared to the Western United States.

\section{Reliability of the Geochemical Maps}

A visual comparison of the sample-locality map (fig. 1) with each of the geochemical maps (figs. 3-24) shows no obvious geochemical patterns unique to either of the two sampling phases. For K, we have also estimated the correlation between pairs of neighboring samples, one originating in phase 1 and the other in phase 2 (fig. 26). The correlation coefficient for 31 such pairs is 0.65 , which is significant at $p<0.01$. These results and the discussion in the Chemical Analysis section indicate that differences in analytical methods in the two phases of the project do not cause errors that overshadow the sampling errors.

The reliability of the obtained geochemical patterns can be judged by other comparisons. As pointed out by Darnley (1993), surface K abundance obtained by airborne gamma-ray spectrometry can provide an independent reference against which $\mathrm{K}$ distribution derived from sampling of surficial materials may be evaluated. Figure 27 shows the K map of the conterminous United States derived from aerial gamma-ray surveys (Duval and others, 1990; Duval and Riggle, 1999). A visual comparison of this map with the K map based on the ultra low density data of Shacklette and Boerngen (1984) (fig. 11) shows many similarities.

On both maps there is higher $\mathrm{K}$ abundance in the Western than in the Eastern United States, prominent K lows in the Gulf-Atlantic Coastal Flats, and prominent highs in the western United States from the Big Bend area of Texas across southern New Mexico and Arizona through southeastern California and Nevada. Both maps show what is evidently a redistribution of $\mathrm{K}$ from the upper regions of the Mississippi River system, where the source material is relatively K-rich, to the flood plains of the lower Mississippi, where the local surficial materials are relatively K-poor. In addition, features such as relative K-low areas are seen on both maps in (1) the Pacific

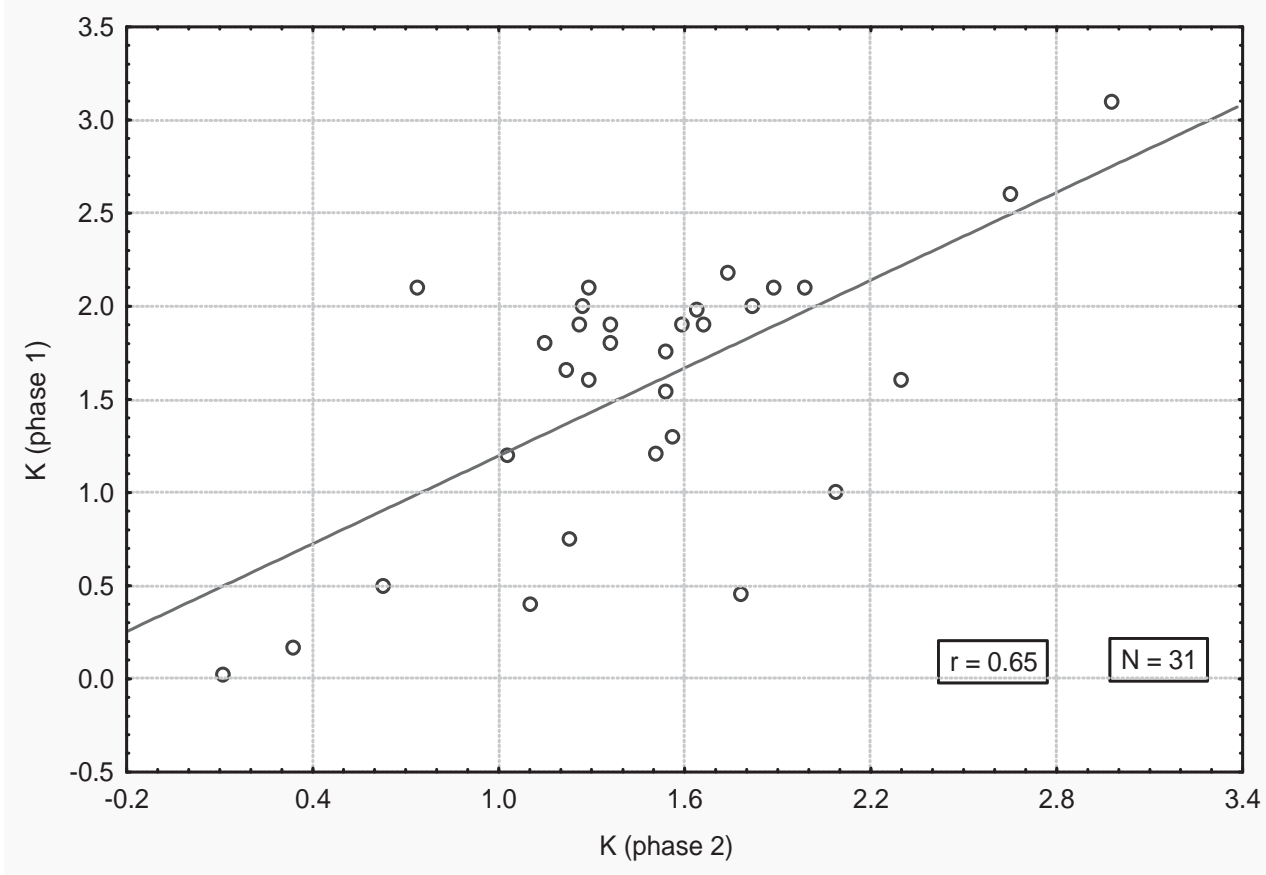

Figure 26. Plot of $\mathrm{K}$ in regolith from sample-collection phase 1 versus sample-collection phase 2. Only pairs separated by less than $25 \mathrm{~km}$ were included. 


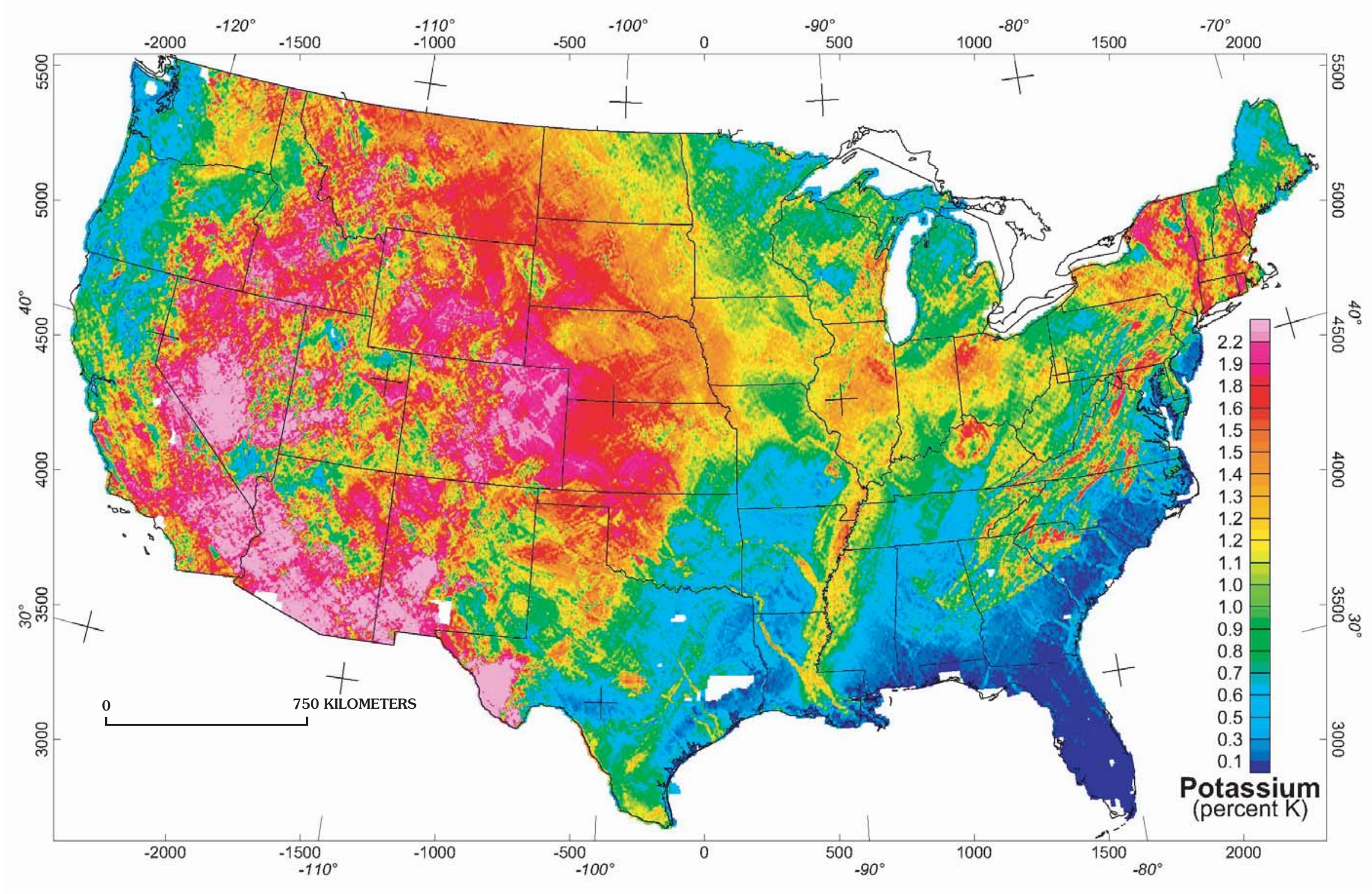

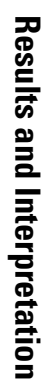

Figure 27. Potassium map of conterminous United States derived from aerial gamma-ray surveys (Duval and others, 1990; Duval and Riggle, 1999). 


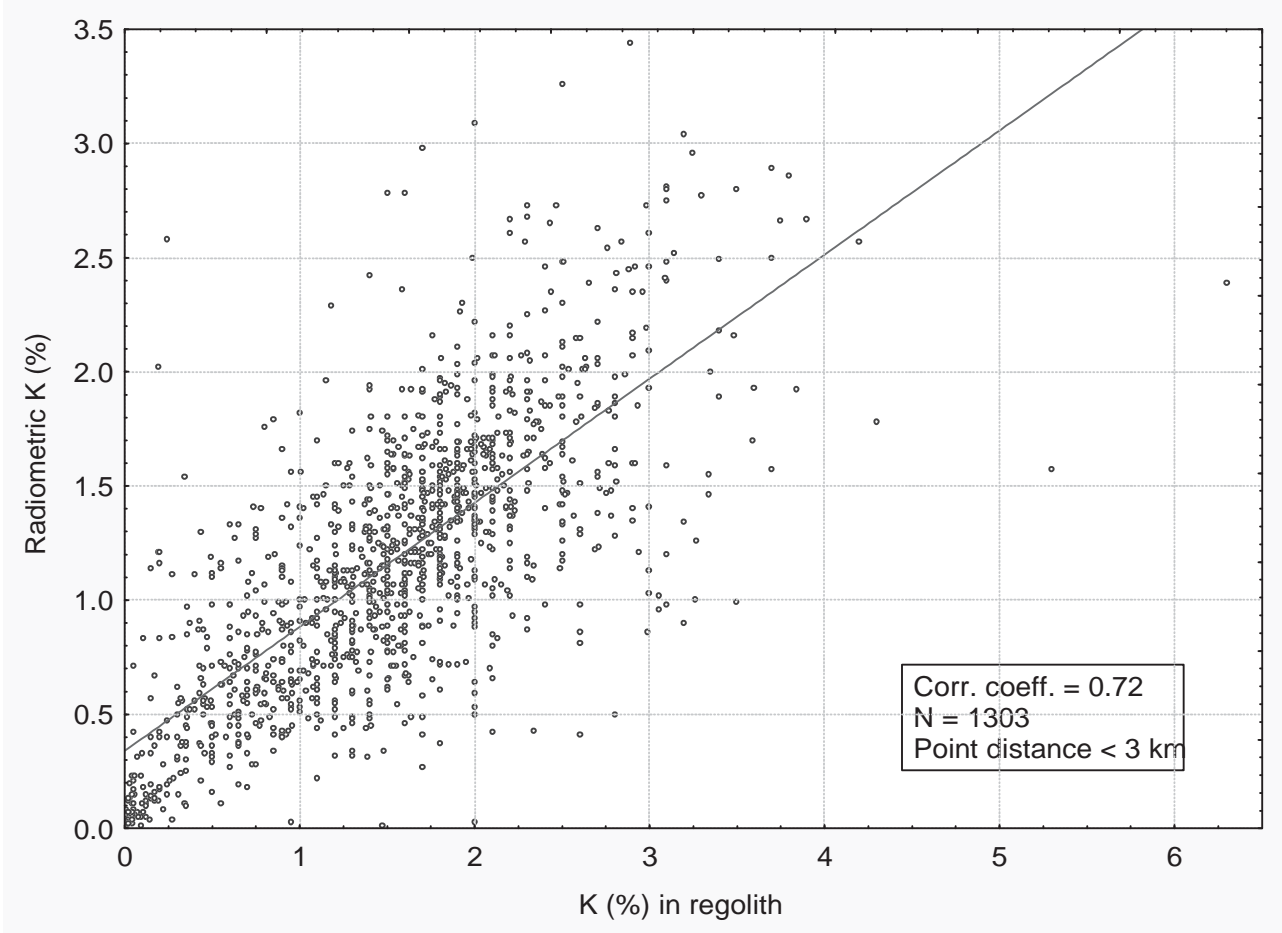

Figure 28. Plot of $\mathrm{K}$ in regolith versus radiometric $\mathrm{K}$ at the corresponding nearest point.

northwest, (2) the area through southern Missouri, eastern Oklahoma, western Arkansas, eastern Texas, and western Louisiana, and (3) the area through southern Kentucky, central Tennessee, eastern Mississippi, and Alabama.

The two data sets of K (regolith chemical analysis and airborne radiometry) were also compared statistically by (1) plotting a scattergram and estimating the correlation coefficient (Pearson's) for the overall covariation (fig. 28) and (2) by mapping a spatially moving correlation coefficient (Spearmanrank) for the survey area (fig. 29). The data pairs needed for these computations were generated by using the raw geochemical data and the radiometric values at the nearest grid point (Phillips and others, 1993) for each regolith sample. The scattergram and the overall coefficient of correlation (N $=1,323$ ) were computed using standard methods. The scattergram (fig. 28) and the significant overall correlation coefficient (0.72) indicate that the two independent data sets reflect the same phenomena.

A moving correlation coefficient was estimated using a method introduced by Bølviken and others (1997). A circle was drawn around each sample site on the geochemical map in such a way that it included the 29 closest neighboring samples. The Spearman-rank correlation coefficient between the chemical and radiometric $\mathrm{K}$ values within the circle was calculated $(29+1=30$ pairs of values, 28 degrees of freedom) and assigned to the site. This procedure was repeated for all 1,323 sample sites. The resulting map shows the regional variation of the correlation coefficient between the two $\mathrm{K}$ data sets for mutually overlapping sets of 30 neighboring samples (fig. 29).

There may be effects of biases in the data. Shacklette and Boerngen (1984) point out apparent differences in values between certain sampling routes. Specifically, they mention high values for $\mathrm{Ce}, \mathrm{Co}, \mathrm{Ga}$, and $\mathrm{Pb}$ predominate on the routes across the Great Plains and the North-Central States, suggesting the possibility of systematic errors in sampling or laboratory analysis. It seems, however, that the smoothing technique to some extent compensates for such errors because they are not easily detected on the colored maps.

\section{Conclusions}

The feasibility of ultra low density geochemical maps may be appraised by their ability to show regional geochemical patterns that (1) indicate large underlying geologic features, (2) reflect the influence of human activity, (3) agree with major features of the geochemical landscape obtained with higher sample density, and (4) correlate with other features such as soil types, climate, vegetation, etc. The examples given in the previous section indicate that many of the variations observed on the accompanying maps meet one or more of these criteria. 
0

1,000 KILOMETERS

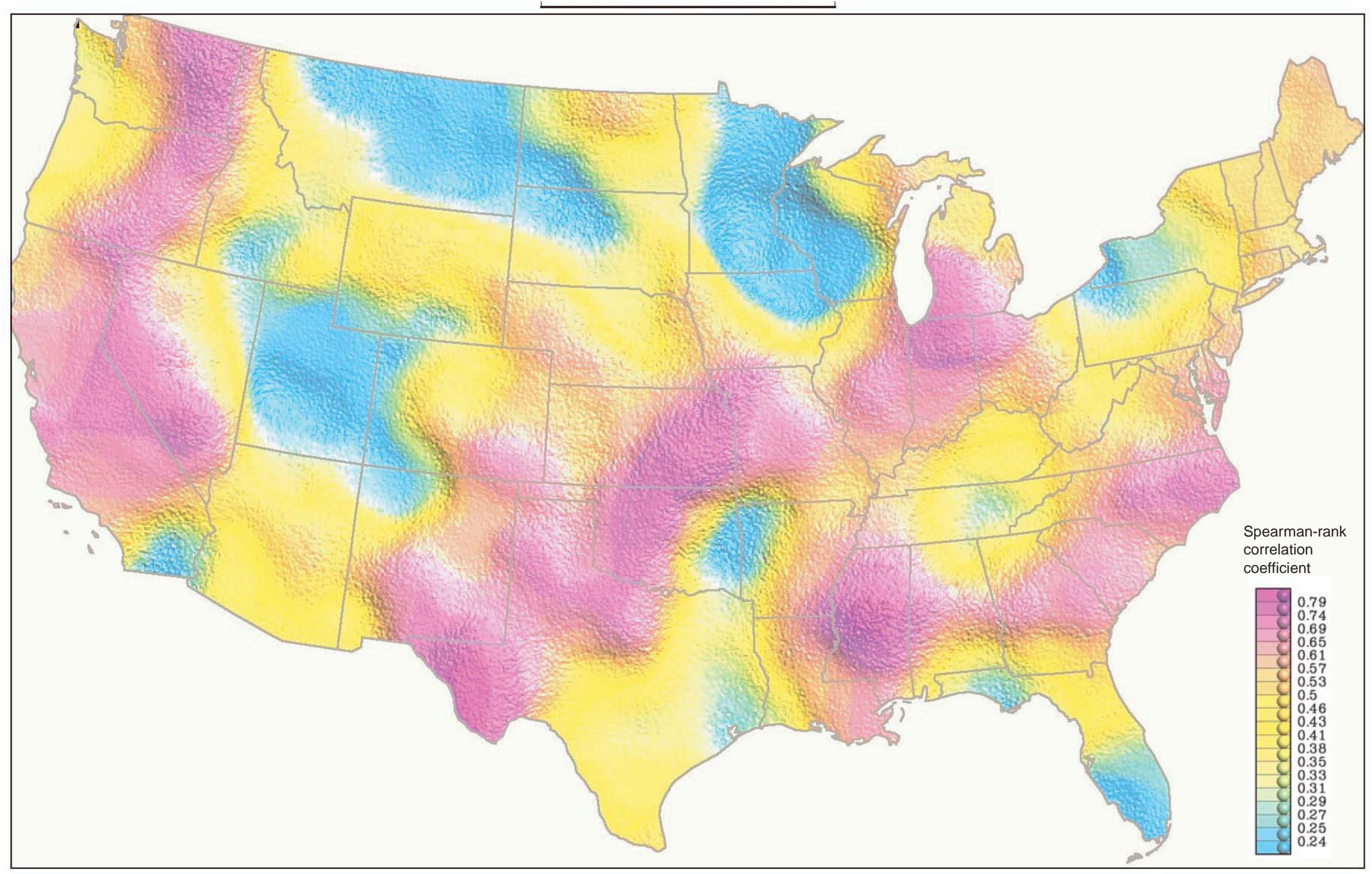

Figure 29. Map of conterminous United States showing the moving correlation (Spearman-rank correlation coefficient) between K in regolith samples (Boerngen and Shacklette, 1981 ) and K determined by airborne gamma-ray surveys (Phillips and others, 1993). 
It is concluded that ultra low density geochemical maps such as those presented in this publication should have poten tial use in various fields since they may (1) establish general baselines against which more specific natural geochemical variations and human-induced perturbations can be recog nized, (2) reflect large underlying geologic features and can therefore be used to delineate geochemical provinces of inter est in exploration for mineral resources, (3) show how geo chemical patterns in the regolith are influenced by natural features such as soil type, climate, and vegetation, (4) provide a basis for research within the field of geomedicine (envi ronmental geochemistry and health), and (5) show large geo chemical contrasts between continents, perhaps indicating that even sparser sampling than that used here could be adequate for global geochemical mapping.

\section{Acknowledgments}

We acknowledge the support of the Geological Surveys of Finland, Norway and the United States. We thank Arthur G. Darnley and Robert G. Garrett of the Geological Survey of Canada and the International Geological Correlation Program Projects 259/360 for constructive comments during the planning and preparation of maps and manuscript, and Rolf Nilsen of the Geological Survey of Norway for performing the moving correlation analysis of the two potassium data sets. Thoughtful reviews by G.K. Lee and S.M. Smith of the U.S. Geological Survey greatly improved the manuscript.

\section{References Cited}

Ahlbrandt, T.S., and Fryberger, S.G., 1980, Eolian deposits in the Nebraska Sand Hills: U.S. Geological Survey Professional Paper 1120-A, 24 p.

Björklund, A., and Gustavsson, N., 1987, Visualization of geochemical data on maps: New options. Journal of Geochemical Exploration, v. 29, p. 89-103.

Björklund, A., and Lummaa, M., 1983, Representation of regional, local and residual variability of geochemical data by means of filtering techniques: Irkutsk, USSR, Proceedings of the 2nd International Symposium on Methods of Prospecting Geochemistry, p. 25-34, [translated into Russian].

Boerngen J.G., and Shacklette. H.T., 1981, Chemical analyses of soils and other surficial materials of the conterminous Unites States: U.S. Geological Survey Open-File Report 81-197, 143 p.

Bølviken, B., Nilsen, R., and Ukkelberg, $\AA .$, 1997, A new method for spatially moving correlation analysis in geomedicine:. Environmental Geochemistry and Health, v. 19, p. 143-153.

Bølviken, B., Stokke, P.R., Feder, J., and Jøssang, T., 1992, The fractal nature of geochemical landscapes: Journal of Geochemical Exploration, v. 43, p. 91-109.
Conner, J.J., Feder, G.L., Erdman, J.A., and Tidball, R.R., 1972, Environmental geochemistry studies in Missouri-A multidisciplinary study: Montreal, Canada, 24th International Geological Congress, August 1972, Symposium 1, p. 7-14.

Dane, C.H., and Bachman, G.O., 1965, Geologic Map of New Mexico: U.S. Geological Survey in cooperation with New Mexico Institute of Mining and Technology, State Bureau of Mines and Mineral Resources Division, and the University of New Mexico, Department of Geology, scale 1:500,000.

Darnley, A.G., 1993, Some notes on the importance of airborne gamma-ray spectrometry in International geochemical mapping: Journal of Geochemical Exploration, v. 49, p. 201-212.

Darnley, A.G., Björklund, A.J., Bølviken, B., Gustavsson, N., Plant, J.A., Steenfelt, A., Tauchid, M., Xie, Xuejing 1995, A global geochemical database for environmental and resource management, recommendations for international geochemical mapping: Final Report for IGCP 259: UNESCO Earth Sciences Report No. 19, 122 p.

Davenport, P.H., Nolan, W.L., and Kilfoil, G.J., 1991, Image-processing of geochemical data to map geological structures and alteration zones, in Mrna, F., ed., Exploration Geochemistry 1990: Prague, Czechoslovakia, Proceedings of the Third International Joint Symposium of the IAGC and the AEG, Geological Survey, Prague, and Czech Academy of Sciences, p 57-91.

Duval, J.S., 1990, Modern aerial gamma-ray spectrometry and regional potassium map of the conterminous United States: Journal of Geochemical Exploration, v. 39, p. 249-253.

Duval, J.S., Jones, W.J., Riggle, F.R., and Pitkin, J.A., 1990, Potassium and thorium maps of the conterminous United States: U.S. Geological Survey Open-File Report 90-338, 17 p., scale 1:2,500,000.

Duval, J.S., and Riggle, F.R., 1999, Profiles of gamma-ray and magnetic data from aerial surveys over the conterminous United States: U.S. Geological Survey Digital Data Series DDS-0031, 3 discs.

Eden, P., and Björklund, A., 1994, Ultra-low density sampling of overbank sediment in Fennoscandia: Journal of Geochemical Exploration v. 51, p. 265-289.

Efron, B., and Tibshirani, R., 1991, Statistical data analysis in the computer age: Science, v. 253, p. 390-395.

Geologic Atlas of Texas, 1977, Del Rio sheet: University of Texas at Austin, Bureau of Economic Geology, scale 1:250,000.

Geologic Atlas of Texas, 1981, Sonora sheet: University of Texas at Austin, Bureau of Economic Geology, scale 1:250,000.

Geologic Atlas of Texas, 1982, Fort Stockton sheet: University of Texas at Austin, Bureau of Economic Geology, scale 1:250,000.

Goldhaber, M.B., Irwin, E.R., Atkins, J.B., Lee, Rob, Zappia, Humbert., Black, D.D., and Finkelmen, R.B., 2000, Environmental impact of elevated arsenic in southern Appalachian Basin coals, in Centeno, J.A., Collery, Philippe, Vernet, Guy, Finkelman, R.B., Gibb, Herman, and Etienne, Jean-Claude, eds., Metal lons in Biology and Medicine: Volume 6, Proceedings of the Sixth International Symposium on Metal lons in Biology and Medicine [held in San Juan, Puerto Rico, May 7-10, 2000], p. 38-40.

Gonzales, R.G., and Winz, P., 1987, Digital image processing (2nd ed.): Reading, Pa., Addison-Wesley, 503 p. 
Grossman, J.N., 1998, National geochemical atlas: The geochemical landscape of the conterminous United States derived from stream sediment and other solid sample media analyzed by the National Uranium Evaluation (NURE) Program: U.S. Geological Survey OpenFile Report 98-622, version 3.01, CD-ROM.

Gustavsson, N., 1995, Geochemical maps showing Bootstrap estimates of the moving weighted median [abs.], in Halleraker, J., and Misund, A., eds., The 5th Seminar on Hydrogeology and Environmental Geochemistry, B. Bølviken Seminar 1995: NGU Report 95.138, $1 \mathrm{p}$.

Gustavsson, N., Lampio, E., Nilsson, B., Norblad, G., Ros, F., and Salminen, R. 1994, Geochemical maps of Finland and Sweden: Journal of Geochemical Exploration, v. 51, p. 143-160.

Gustavsson, N., Lampio, E., and Tarvainen, T. 1997, Visualization of geochemical data on maps at the Geological Survey of Finland: Journal of Geochemical Exploration, v. 59, p. 197-207.

Hammond, E.H., 1964, Analysis of properties in land form mapping: Annals of the Association of American Geographers, v. 54, p. 11-23.

Hintze, L.F., 1980, Geologic map of Utah: Utah Geological and Mineral Survey, scale 1:500,000.

Howarth, R.J., 1983, Mapping, in Howarth, R.J., ed., Statistics and Data Analysis in Geochemical Prospecting: Amsterdam, Elsevier Scientific Publishing Company, Handbook of Exploration Geochemistry, Volume 2, p. 111-205.

Huffman, C., Jr., and Dinnin, J.I., 1976, Analysis of rocks and soil by atomic absorption spectrometry and other methods, in Miesch, A.T., Geochemical Survey of Missouri-Methods of Sampling, Laboratory Analysis and Statistical Reduction of Data: U.S. Geological Survey Professional Paper 954-A, p. 12-14.

Huntting, M.T., Bennett, W.A.G., Livingston, V.E., Jr., and Moen, W.S., 1961, Geologic map of Washington: Washington Department of Conservation, Division of Mines and Geology, scale 1:500,000.

Jennings, C.W., 1977, Geologic map of California: California Division of Mines and Geology, California Geologic Data Map Series, Map No. 2 , scale $1: 750,000$.

Koljonen, T., ed., 1992, The geochemical atlas of Finland, Part 2: Till: , Espoo, Geological Survey of Finland, $218 \mathrm{p}$.

Lahermo, P., Ilmasti, M., Juntunen, R., and Taka, M, 1990, The geochemical atlas of Finland, Part 1: The hydrogeochemical mapping of Finnish groundwater: Espoo, Geological Survey of Finland, $66 \mathrm{p}$.

Lahermo, P., Väänänen, P., Tarvainen, T., and Salminen, R., 1996, The geochemical atlas of Finland, Part 3: Environmental geochemistry-Stream waters and sediments: Espoo, Geological Survey of Finland, $149 \mathrm{p}$.

Miesch, A.T., 1976, Geochemical survey of Missouri-Methods of sampling, laboratory analysis, and statistical reduction of data: U.S. Geological Survey Professional Paper 954-A, 39 p.

Myers, A.T., Havens, R.G., and Dunton, P.J, 1961, A spectrochemical method for the semiquantitative analysis of rocks, minerals and ores: U.S. Geological Survey Bulletin 1084-I, p. 207-229.

Neiman, H., 1976, Analysis of rocks, soils, and plant ashes by emission spectroscopy, in Miesch, A.T., Geochemical Survey of Missouri-Methods of Sampling, Laboratory Analysis, and Statistical Reduction of Data: U.S. Geological Survey Professional Paper 954-A, p. 14-15.

Phillips, J.D., Duval, J.S., and Ambroziak, R.A., 1993, National geophysical data grids; gamma-ray, gravity, magnetic and topographic data for the conterminous United States: U.S. Geological Survey Digital Data Series DDS-0009, CD-ROM.

Plumlee, G.S., Smith, S.M., Toth, M.I., and Marsh, S.P., 1993, Integrated mineral-resource and mineral-environmental assessments of public lands: Applications for land management and resource planning: U.S. Geological Survey Open-File Report 93-571, 18 p.

Ransome, F.L., 1908, The geology and ore deposits of the Coeur d'Alene district, Idaho: U.S. Geological Survey Professional Paper 62, $203 \mathrm{p}$.

Shacklette, H.T., and Boerngen, J.G., 1984, Element concentrations in soils and other surficial materials of the conterminous United States: U.S. Geological Survey Professional Paper 1270, 105 p.

Shacklette, H.T., Hamilton, J.C., Boerngen, J.G., and Bowles, J.M., 1971, Elemental composition of surficial materials in the conterminous United States: U.S. Geological Survey Professional Paper 574-D, $69 \mathrm{p}$.

Snyder, J.P., 1987, Map projections-A working manual: U.S. Geological Survey Professional Paper 1395, 383 p.

Stewart, J.H., and Carlson, J.E., 1978, Geologic map of Nevada: U.S. Geological Survey and Nevada Bureau of Mines and Geology, scale 1:500,000.

Strauss, P.S., 1990, A realistic lighting model for computer animators: Computer Graphics and Applications, v. 10, p. 56-64.

Stuart A., and Ord, J.K., 1987, Kendall's advanced theory of statistics, volume 1: Distribution theory (5th ed.): London, Charles Griffin and Company Limited, $604 \mathrm{p}$.

Swanson, D.A., Wright, T.L., Hooper, P.R., and Bentley, R.D., 1979, Revisions in stratigraphic nomenclature of the Columbia River Basalt Group: U.S. Geological Survey Bulletin 1457-G, 59 p.

Tidball, R.R., 1974, Average composition of agricultural soils in Missouri counties: U.S. Geological Survey Open-File Report 74-66, $25 \mathrm{p}$.

Tidball, R.R., 1976, Geochemical survey of Missouri-Chemical variation of soils in Missouri associated with selected levels of the soil classification system: U.S. Geological Survey Professional Paper 954-B, $16 \mathrm{p}$.

Titley, S.R., 1982, Geologic setting of porphyry copper deposits, southeastern Arizona, in Titley, S.R., ed., Advances in Geology of the Porphyry Copper Deposits, Southwestern Northern America: Tucson, University of Arizona Press, p. 37-58.

Tweto, Ogden, and Sims, P.K., 1963, Precambrian ancestry of the Colorado mineral belt: Geological Society of America Bulletin, v. 74, p. 991-1014.

U.S. Soil Conservation Service, 1969, Distribution of principal kinds of soils-Orders, Suborders, and Great Groups, in National Atlas of the United States of America: U.S. Geological Survey, sheet 86, 2 p. 
Wahlberg, J.S., 1976, Analysis of rocks and soils by X-ray fluorescence spectrometry, in Miesch, A.T., Geochemical Survey of Missouri-Methods of Sampling, Laboratory Analysis and Statistical Reduction of Data: U.S. Geological Survey Professional Paper 954-A, p. 11-12.

Walker, G.W., and MacLeod, N.S., 1991, Geologic map of Oregon: U.S. Geological Survey, scale 1:500,000.

Ward, F.N., Lakin, H.W., Canney, F.C., and others, 1963, Analytical methods used in geochemical exploration by the U.S. Geological Survey: U.S. Geological Survey Bulletin 1152, 100 p.

Wilson, E.D., Moore, R.T., and Cooper, J.R., 1969, Geologic map of Arizona: Arizona Bureau of Mines and U.S. Geological Survey, scale 1:500,000.

Xie Xuejing, and Ren Tianxiang, 1993, National geochemical mapping and environmental geochemistry-Progress in China, in Davenport, P.H., ed., Geochemical Mapping: Journal of Geochemical Exploration, v. 49, p. 15-34.

Manuscript approved for publication July 31, 2001

Published in the Central Region, Denver, Colorado

Editing, page layout, photocomposition-Richard W. Scott, Jr.

Cover design-Carol A. Quesenberry

Graphics by the authors 